\title{
Geochemistry, Zircon U-Pb Geochronology, and Lu-Hf Isotopes of the Chishan Alkaline Complex, Western Shandong, China
}

\author{
Pengfei Wei ${ }^{1,2,3}$, Xuefeng Yu ${ }^{1, *}$, Dapeng $\mathrm{Li}^{1, *}$, Qiang Liu ${ }^{1}$, Lidong $\mathrm{Yu}^{3}$, Zengsheng $\mathrm{Li}^{1}{ }^{1}$, \\ Ke Geng ${ }^{1}$, Yan Zhang ${ }^{1}$, Yuqin Sun ${ }^{1}$ and Naijie Chi ${ }^{1}$ \\ 1 Shandong Institute of Geological Sciences, Shandong Key Laboratory of Geological Processes and Resource \\ Utilization in Metallic Minerals, Key Laboratory of Gold Mineralization Processes and Resources Utilization \\ Subordinated to the Ministry of Land and Resources, Jinan 250013, China; pfeiwei@126.com (P.W.); \\ lqiang715@163.com (Q.L.); lizengsheng@126.com (Z.L.); gengke@126.com (K.G.); sddkyzy@163.com (Y.Z.); \\ sunyuqin86@163.com (Y.S.); chinaijie@163.com (N.C.) \\ 2 Shandong Provincial Key Laboratory of Depositional Mineralization \& Sedimentary Mineral, \\ Shandong University of Science and Technology, Qingdao 266590, China \\ 3 School of Earth Sciences and Resources, China University of Geosciences, Beijing 100083, China; \\ yldongy@126.com \\ * Correspondence: xfengy@sohu.com (X.Y.); dpengli@126.com (D.L.); Tel.: +86-0531-8655-6925 (X.Y.); \\ +86-0531-8655-8802 (D.L.)
}

Received: 26 March 2019; Accepted: 5 May 2019; Published: 13 May 2019

\begin{abstract}
Mass alkaline magmatic activities in Western Shandong during the late Mesozoic controlled the mineralization processes of gold and rare earth element (REE) polymetallic deposits in the region. The Chishan alkaline complex is closely associated with the mineralization of the Chishan REE deposit, which, as the third largest light REE deposit in China following the Baiyenebo (Inner Mongolia) and Mianning (Sichuan) deposits, is considered a typical example of alkaline rock mineralization throughout the North China Craton. To determine how the Chishan alkaline complex and REE deposit interact with each other, a systematic study was conducted on the petrology, rock geochemistry, zircon $\mathrm{U}-\mathrm{Pb}$ geochronology, $\mathrm{Lu}-\mathrm{Hf}$ isotopes of the quartz syenite, and alkali granite contained in the Chishan alkaline complex. The results reveal that the deposits feature similar geochemical characteristics typical of an alkaline rock series-both are rich in alkali, high in potassium, metaluminous, and poor in $\mathrm{Ti}, \mathrm{Fe}, \mathrm{Mg}$, and $\mathrm{Mn}$. In terms of REEs, the deposits are strongly rich in light REEs but poor in heavy REEs, with weak negative Eu anomalies. In terms of trace elements, they are rich in large ion lithophile elements $\mathrm{Ba}, \mathrm{Sr}$, and $\mathrm{Rb}$ but poor in high field-strength elements $\mathrm{Nb}$, Ta, and Hf. Zircon LA-ICP-MS U-Pb dating indicated that the quartz syenite and alkali granite formed in Early Cretaceous at $125.8 \pm 1.2 \mathrm{Ma}$ and $127.3 \pm 1.0 \mathrm{Ma}$, respectively; their $\varepsilon \mathrm{Hf}(\mathrm{t})$ values are -22.67 to -13.19 , with depleted model ages $\left(\mathrm{T}_{\mathrm{DM}}\right)$ ranging from $1296 \mathrm{Ma}$ to $1675 \mathrm{Ma}$ and crustal model ages $\left(\mathrm{T}_{\mathrm{DM}}{ }^{\mathrm{C}}\right)$ of 2036-2617 Ma. The Chishan alkaline complex originated from partial of the EM I-type (enriched mantle I) lithospheric mantle with assimilation of ancient crustal materials. The complex is of the same origin as the REE deposit, and developed in an extensional setting that resulted from plate subduction and lithospheric thinning and upwelling in the eastern area of the North China Craton.
\end{abstract}

Keywords: Chishan alkaline complex; rock geochemistry; zircon $\mathrm{U}-\mathrm{Pb}$ dating; Lu-Hf isotopes

\section{Introduction}

In late Mesozoic, the tectonic regime of the North China Craton changed from an extrusional to an extensional environment. The mass lithospheric thinning [1-8] and extensive uptrusion 
of asthenospheric mantle materials led to violent magmatic activities, accompanied by the mineralization of gold and rare earth elements (REE) polymetallic deposits [9-13]. Intense and frequent magmatic activities dating back to 130-120 Ma, in particular, controlled the formation of a large number of deposits [14-16]. In East China's Shandong Province, the acidic magmas to the east of the Yishu fault zone, such as the Guojialing-style granite, controlled the formation of large-sized gold deposits in Eastern Shandong (e.g., the Linglong, Rushan, and Wulongshan gold deposits) and the polymetallic deposits in the eastern part of Eastern Shandong (e.g., Meishan and Taocun iron deposits) [11,14,17-22]. The alkaline magmas to the west of the fault zone controlled the formation of gold and REE deposits in Western Shandong $[14,20,22]$. Examples include the Longbaoshan alkaline complex, which controlled the mineralization of the Longbaoshan gold deposit [23,24], and the Chishan alkaline complex, which controlled the mineralization of the Chishan REE Deposit [25-30]. These alkaline magmas usually originate from the upper mantle and have experienced complicated underplating, contamination, and evolution, recording the tectonic evolution and lithospheric thinning of the North China Craton during late Mesozoic.

The Chishan alkaline complex in Western Shandong is closely associated with the mineralization of the Chishan REE deposit which, as the third largest light REE (LREE) deposit in China following the Baiyenebo (Inner Mongolia) and Mianning (Sichuan) deposits, is considered as a typical example of alkaline rock mineralization throughout the North China Craton [25], and valued by scientific research institutes and mining enterprises [25,27,28,31-35]. In particular, the recent discovery of the REE mineralization bodies from the neighboring Shagou (Xuecheng) and Longbaoshan (Zaozhuang) alkaline complexes has triggered a considerable interest in this alkaline magmatic rock series. However, despite the understandings on the formation age $[25,35]$ and geochemistry $[28,32,33]$ of this complex, the lack of systematic research still limits further identification of the local tectonic magma evolution and REE accumulation processes of the area.

In this study, we attempted to discuss the magmatic origin, evolution, and tectonic setting of these alkaline magmas through a systematic study on the petrology, geochemistry, zircon $\mathrm{U}-\mathrm{Pb}$ geochronology, and Lu-Hf isotopes of the Chishan alkaline complex, with a view to further gain insights into the mechanisms behind the lithospheric thinning of the North China Craton and the genetic connections between alkaline rocks and polymetallic deposits.

\section{Regional Geology}

The Chishan alkaline complex lies near the Chishan village about $18 \mathrm{~km}$ southeast of Weishan County of Zaozhuang City, Shandong Province. Tectonically, this complex belongs to the Luxi Block at the southeastern margin of the North China Craton and the west side of the Tanlu fault zone (Figure 1a) $[28,29]$. The Luxi Block is bounded by the Tanlu fault zone to the east, the Liaocheng-Lankao fault zone to the west, the south of the Qihe-Guangrao fault to the north, and the Fengpei fault to the south (Figure 1b) [36-45]. The exposed formations in the study area include the Neoarchean Taishan rock group, Paleozoic Cambrian to Permian carbonate and clastic rocks, Mesozoic Triassic to Cretaceous clastic and volcanic rocks, and Cenozoic clastic rocks (Figure 1b), with the Neoarchean granodiorite constituting the crystalline basement. In this area, the Yanshanian intermediate-to-alkaline complexes consisting of diorite porphyrite, syenite, syenite porphyrite, diabase, and lamprophyre mostly occur in forms of batholiths, stocks, or dykes. The representative rock bodies include the Shagou, Tongshi, Chishan, and Longbaoshan volcanic-intrusive complexes composed of monzonitic-orthofelsic rocks. 


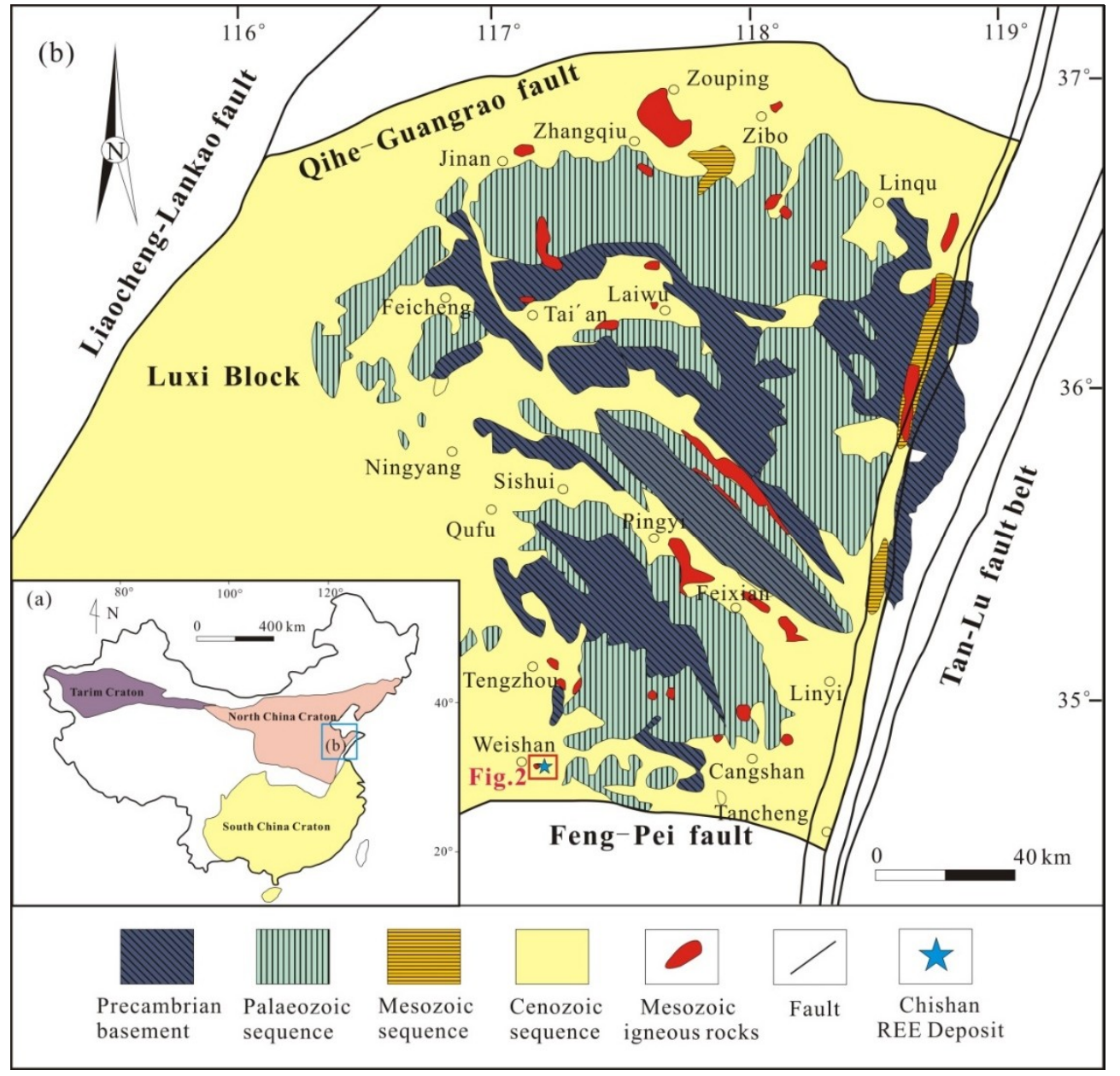

Figure 1. Simplified geological map showing the major tectonic units in China (a) and regional geological sketch of Western Shandong (b). (a) Geologic and tectonic map of China and the location of Luxi Block, modified after [40]. (b) Geological map of the Luxi Block, modified after [37].

The principal part of the Chishan alkaline complex comprises quartz syenite, aegirine quartz syenite, and alkali granite. The complex stretches in the NE-SE orientation, intruding into the early granodiorite and interfacing with the country rock like irregular branches. Varying degrees of alkaline metasomatism can be observed along most parts of the contact. The outcrop of this complex, occupying an area of an area of $0.5 \mathrm{~km}^{2}$, is almost fully covered by Quaternary except for sporadic bedrock outcrops at the Chishan hilltop. The Chishan alkaline complex is primarily controlled by tectonic faults. Tectonic fissures in the rocks are often filled up by rare earth veins and occur in the NW orientation as single veins, spiderwebs, or disseminations (Figure 2) [46]. 


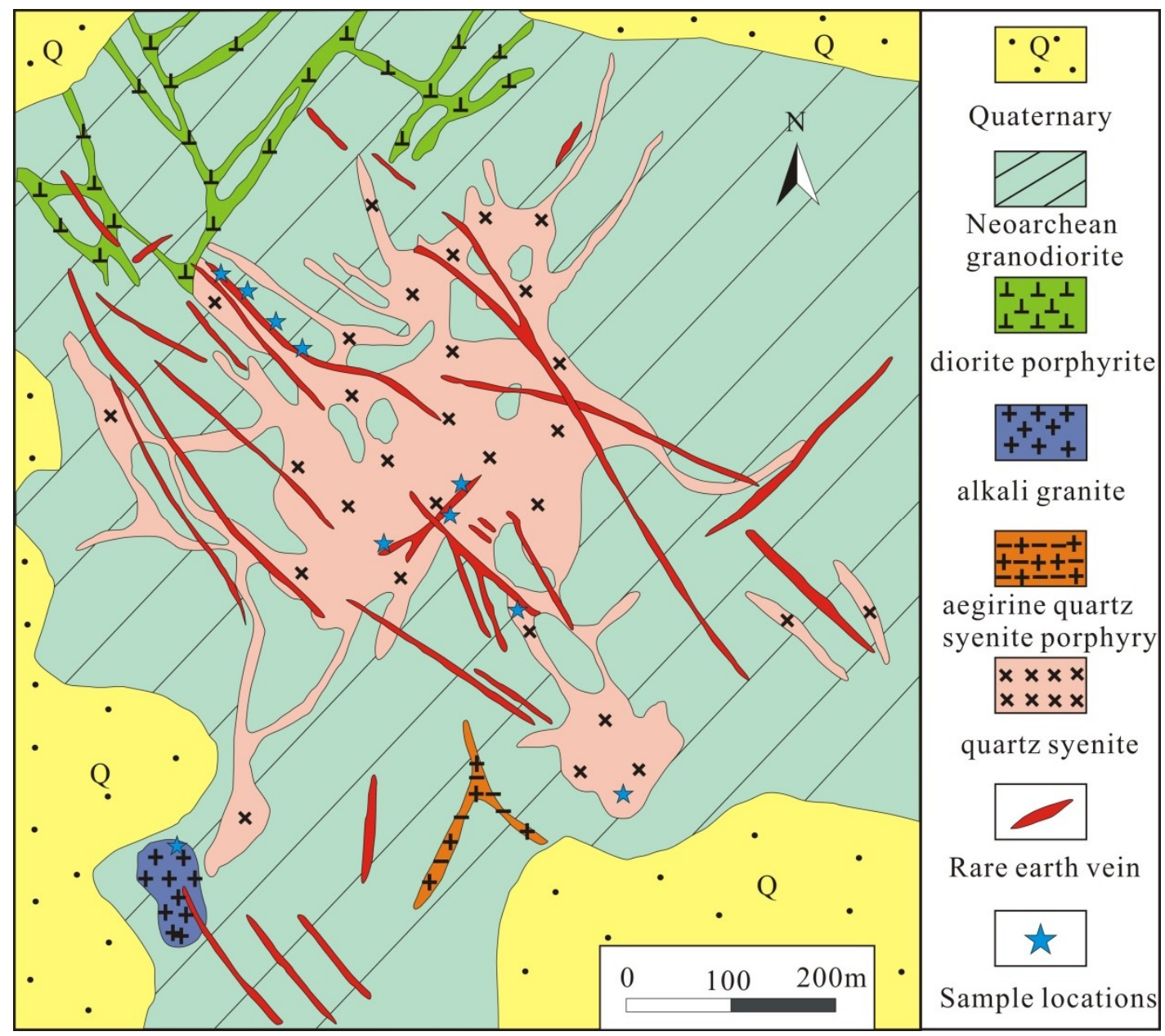

Figure 2. Regional geological map of the Chishan alkaline complex, modified after [46].

\section{Petrology and Petrography}

The quartz syenite is grayish white or light flesh pink in color (Figure 3a), porphyroid or porphyritic in texture, and massive in structure. The mineral components mainly include K-feldspar, plagioclase, quartz, with portions of hornblende. Microscopy revealed a fine-grained porphyritic texture. The phenocrysts primarily include K-feldspar $( \pm 10 \%)$ and a small amount of hornblende $( \pm 1 \%)$. The matrix, which is primarily composed of K-feldspar $( \pm 53 \%)$, plagioclase $( \pm 10 \%)$, quartz $( \pm 10 \%)$, and hornblende $( \pm 5 \%)$, exhibits a xenomorphic platy, columnar-granular, or irregular granular shape, and $0.01-1.0 \mathrm{~mm}$ grain size. The K-feldspar phenocrysts, which mainly consists of orthoclase, features a platy or irregular granular texture and $1.8-2.5 \mathrm{~mm}$ grain size, with detectable Carlsbad twinning (Figure $3 \mathrm{c}$ ) and zonal structures, and are mostly clayized. The hornblende $( \pm 1 \%)$ phenocrysts are columnar in shape, approximate $1.2 \mathrm{~mm}$ in grain size, green to olive green in color (Figure 3c,e), and have been partly replaced by epidote and chlorite. The quartz occurs interstitially between feldspar grains (Figure 3e). 

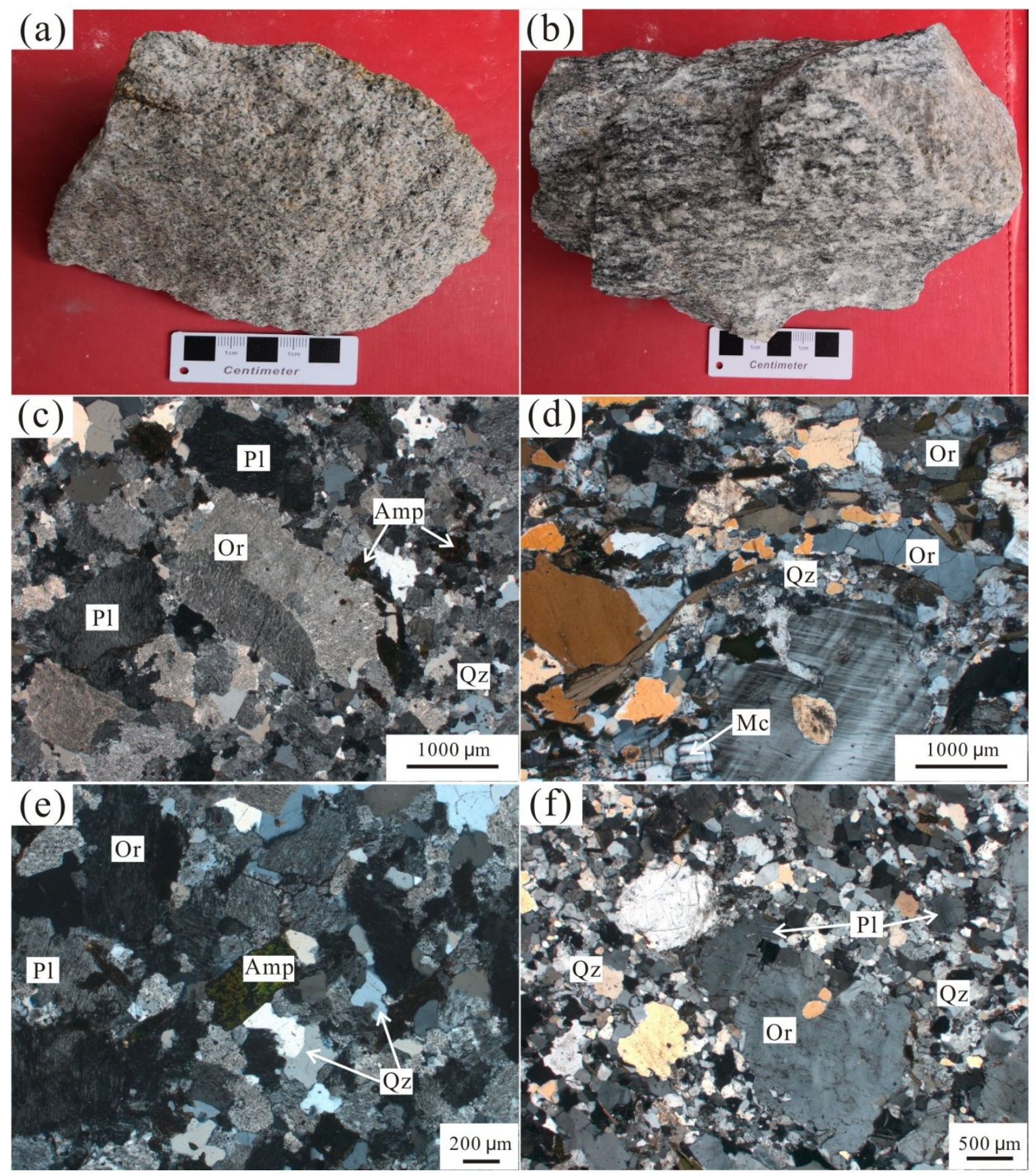

Figure 3. Petro-mineralogical diagram of the Chishan alkaline complex: (a) Quartz syenite; (b) alkali granite; (c) Carlsbad twins of the syenite; (d) crosshatch twins of the microcline; (e) hornblende occuring in columnar form; (f) quartz occurs interstitially between the feldspar grains. The (c) and (e) photos under the microscope refer to the sample present in (a); the (d) and (f) photos under the microscope refer to the sample present in (b). Qz-quartz; Or-orthoclase; Pl-plagioclase; Amp-amphibole; Mc-microcline.

The alkali granite features fine-grained granite texture and massive structure (Figure $3 b$ ). Microscopy revealed a fine-grained, subhedral granular texture. The main mineral components include orthoclase $( \pm 65 \%)$, microcline $( \pm 10 \%)$, quartz $( \pm 20 \%)$, and small fractions of biotite $( \pm 3 \%)$ and epidote $( \pm 1 \%)$. Accessory minerals include sphene and magnetite. The orthoclase is subhedral columnar or granular in shape with Carlsbad twinning (Figure 3d) and evident perthitic texture. The microcline is subhedral columnar in shape and $1-5 \mathrm{~mm}$ in grain size with crosshatch twinning (Figure 3d). The quartz is xenomorphic granular in shape and approximates $0.02-1.2 \mathrm{~mm}$ in grain size; 
a portion of the quartz occurs interstitially between other minerals in fine granular forms (Figure 3f). The biotite is layered with about $0.1-1 \mathrm{~mm}$ by $0.02-0.2 \mathrm{~mm}$ in grain size, and notably pleochroism; the rock is reddish brown to sepia and appears as sandy beige or olive green to green. Some of the biotite is associated with epidote.

\section{Samples and Analysis}

All 12 samples used for our study originated from the fresh alkaline rocks of the Chishan REE deposit. Six samples were quartz syenite, and the other six were alkali granite. Ten samples were collected from the $-160 \mathrm{~m}$ level of the deposit, and two were obtained from the surface outcrop. Figure 2 shows the exact sampling locations. Except for samples 18CS-01 (quartz syenite) and 18CS-27 (alkali granite) on which zircon dating analysis was performed, the total rock major and trace element analyses were performed on all other 10 samples.

\subsection{Total Rock Major and Trace Element Analysis}

The total rock major and trace element analyses were performed by Beijing Createch Testing Technology Co., Ltd. (Beijing, China). Ten fresh quartz syenite and alkali granite samples were crushed to smaller than 200 mesh. For the major elements, the lithium borate plus lithium nitrate melting method and X-ray fluorescence spectrometry (XRF-1800) with an accuracy higher than $1 \%$ were used. For the trace elements, the lithium borate melting method and quantitative inductively-coupled plasma (ICP) spectrometry (Agilent 7500ce) with an accuracy better than 5\% were used. For REEs, the ICP-MS (Agilent 7500ce ICP-MS) with an accuracy of better than $5 \%$ was used. Table 1 presents the analysis results.

\subsection{Zircon $\mathrm{U}-\mathrm{Pb}$ Dating}

Monomineral separation for zircon dating was completed by the Fengze Source Rock and Mineral Test Technology Co., Ltd. (Langfang, China); target fabrication, transmittance and reflectance measurement, and cathode luminescence (CL) photography and testing were all completed by Beijing Createch Testing Technology Co., Ltd. (Beijing, China). Further details about the target fabrication and testing are described in the work of Song et al. [47]. All of the zircons were studied with micrographs and cathode luminescence $(\mathrm{CL})$ images to illustrate their microstructures. The zircon $\mathrm{U}-\mathrm{Pb}$ compositions were determined using a sensitive high-resolution laser ablation multi-collector inductively-coupled plasma source mass spectrometer (AnalytikJena PlasmaQuant MS Elite ICP-MS) composed of an ESI NWR $193 \mathrm{~nm}$ FX laser and a Neptune mass spectrometer. Helium was used as the gas carrier for denudation material. The analytical spot sizes were $35 \mu \mathrm{m}$, but each spot was rastered over $120 \mu \mathrm{m}$ for three minutes to remove common $\mathrm{Pb}$ on the zircon surfaces. Five consecutive scans were performed for each zircon spot. The analysis process is described in the work of Yuan et al. [48]. The final test data were processed with ICP-MS DataCal [49]. Finally, the U-Pb age concordia plot was developed, and the weighted average ages were calculated using ISOPLOT 3.70 [50]. Table 2 presents the analysis results.

\subsection{Zircon $\mathrm{Lu}-\mathrm{Hf}$ Isotopes}

Zircon Hf isotopes were measured with a Neptune system in or near the same position used for $\mathrm{U}-\mathrm{Pb}$ dating analysis. The laser and mass spectrometers used were the same as previously described for zircon $\mathrm{U}-\mathrm{Pb}$ dating test. The analysis conditions, models of instruments, and analysis processes are described in the work of Geng et al. [51]. During the analysis, the $\varepsilon \mathrm{Hf}(\mathrm{t})$ values were calculated by relying on the zircon $\mathrm{U}-\mathrm{Pb}$ ages at the measuring points. For the purpose of this study, the ${ }^{176} \mathrm{Lu}$ decay constant of $1.867 \times 10^{-11}$ year ${ }^{-1}$ [52], chondrite ${ }^{176} \mathrm{Lu} /{ }^{177} \mathrm{Hf}$ ratio of 0.0332 , and ${ }^{176} \mathrm{Hf} /{ }^{177} \mathrm{Hf}$ ratio of 0.282772 were used [53]. The depleted mantle model age $\left(\mathrm{T}_{\mathrm{DM}}\right)$ was calculated at the present ${ }^{176} \mathrm{Lu} /{ }^{177} \mathrm{Hf}$ ratio of 0.0384 and ${ }^{176} \mathrm{Hf} /{ }^{177} \mathrm{Hf}$ ratio of 0.28325 of the depleted mantle [54]. The formulas for calculating are shown below [55]. In the formulas, $f \mathrm{cc}, f \mathrm{~s}$ and $f_{\mathrm{DM}}$ respectively represent the $f_{\mathrm{Lu} / \mathrm{Hf}}$ 
of the large continental crust, sample, and depleted mantle, and $\mathrm{T}$ is the crystallization age of zircon. Table 3 provides the analysis results.

$$
\begin{gathered}
\mathcal{E}_{\mathrm{Hf}}(0)=\left(\left({ }^{176} \mathrm{Hf} /{ }^{177} \mathrm{Hf}\right)_{\mathrm{S}} /\left({ }^{176} \mathrm{Hf} /{ }^{177} \mathrm{Hf}\right)_{\mathrm{CHUR}, 0}-1\right) \times 10,000 ; \\
\mathcal{E}_{\mathrm{Hf}}(\mathrm{t})=\left(\left({ }^{176} \mathrm{Hf} /{ }^{177} \mathrm{Hf}\right)_{\mathrm{S}}-\left({ }^{176} \mathrm{Lu} /{ }^{177} \mathrm{Hf}\right)_{\mathrm{S}} \times\left(\mathrm{e}^{\lambda^{\mathrm{t}}}-1\right)\right) /\left(\left({ }^{176} \mathrm{Hf} /{ }^{177} \mathrm{Hf}\right)_{\mathrm{CHUR}, 0}\right. \\
\left.\left.-\left({ }^{176} \mathrm{Lu} /{ }^{177} \mathrm{Hf}\right)_{\mathrm{CHUR}} \times\left(\mathrm{e}^{\lambda^{\mathrm{t}}}-1\right)\right)-1\right) \times 10,000 ; \\
\mathrm{T}_{\mathrm{Hf} 1}=1 / \lambda \times \ln \left[1+\left(\left({ }^{176} \mathrm{Hf} /{ }^{177} \mathrm{Hf}\right)_{\mathrm{S}}-\left(\left({ }^{176} \mathrm{Hf} /{ }^{177} \mathrm{Hf}\right)_{\mathrm{DM}}\right) /\left(\left({ }^{176} \mathrm{Lu} /{ }^{177} \mathrm{Hf}\right)_{\mathrm{S}}-\left({ }^{176} \mathrm{Lu} /{ }^{177} \mathrm{Hf}\right)_{\mathrm{DM}}\right)\right] ;\right. \\
\mathrm{T}_{\mathrm{Hf} 2}=\mathrm{T}_{\mathrm{Hf} 1}-\left(\mathrm{T}_{\mathrm{Hf} 1}-\mathrm{t}\right)\left((f \mathrm{cc}-f \mathrm{~s}) /\left(f \mathrm{cC}-f_{\mathrm{DM}}\right)\right) ; \\
f_{\mathrm{Lu} / \mathrm{Hf}}=\left({ }^{176} \mathrm{Lu} /{ }^{177} \mathrm{Hf}\right)_{\mathrm{S}} /\left({ }^{176} \mathrm{Lu} /{ }^{177} \mathrm{Hf}\right)_{\mathrm{CHUR}}-1 .
\end{gathered}
$$

\section{Results}

\subsection{Analysis Results of Total Rock Major and Trace Elements}

Major element analysis (Table 1) indicated that the quartz syenite features a $\mathrm{SiO}_{2}$ content of $69.02-71.72 \%$, a $\mathrm{Na}_{2} \mathrm{O}+\mathrm{K}_{2} \mathrm{O}$ content of $8.87-10.94 \%$, and $\mathrm{MgO}, \mathrm{CaO}$, and $\mathrm{Fe}_{2} \mathrm{O}_{3}$ contents of $0.15-0.49 \%, 0.73-1.59 \%$, and $0.48-1.92 \%$, respectively. The rock is relatively high in $\mathrm{SiO}_{2}$, rich in alkali, low in $\mathrm{Ti}$ (with a $\mathrm{TiO}_{2}$ content of $0.06-0.17 \%$ ), and rich in $\mathrm{Al}$ (with an $\mathrm{Al}_{2} \mathrm{O}_{3}$ content of $13.51-16.12 \%$ ). On the total alkali versus silica (TAS) diagram, the quartz syenite falls within either the quartz monzonite or granite zone (Figure 4a). The aluminum saturation index (A/CNK) of $0.80-1.00$ suggests that the quartz syenite belongs to the metaluminous series. On the $\mathrm{A} / \mathrm{NK}-\mathrm{A} / \mathrm{CNK}$ diagram, all the samples fall within the metaluminous zone (Figure $4 \mathrm{~b}$ ). The quartz syenite features an alkalinity rate (AR) of 2.58-9.02. On the $\mathrm{AR}-\mathrm{SiO}_{2}$ diagram (Figure 4c), the rock samples were projected into the alkaline rock zone, signifying that the quartz syenite belongs to the alkaline rock series.

The alkali granite features a similar major and trace element geochemistry as the quartz syenite, with a $\mathrm{SiO}_{2}$ content of $64.07-71.66 \%$, a $\mathrm{Na}_{2} \mathrm{O}+\mathrm{K}_{2} \mathrm{O}$ content of $7.62-8.35 \%$, and $\mathrm{MgO}, \mathrm{CaO}$, and $\mathrm{Fe}_{2} \mathrm{O}_{3}$ contents of $0.62-1.55 \%, 2.32-4.14 \%$, and $0.73-2.16 \%$, respectively. The rock is relatively high in $\mathrm{SiO}_{2}$, rich in alkali, low in $\mathrm{Ti}$ (with a $\mathrm{TiO}_{2}$ content of $0.19-0.40 \%$ ), and rich in $\mathrm{Al}$ (with an $\mathrm{Al}_{2} \mathrm{O}_{3}$ content of $14.07-16.75 \%$ ). On the TAS diagram, the alkali granite typically falls within either the quartz syenite or granite zone (Figure $4 \mathrm{a}$ ). The A/CNK value mostly falls within $0.75-1.00$. On the A/NK-A/CNK diagram, the peralkaline contents are mostly found in the metaluminous zone (Figure $4 \mathrm{~b}$ ). The alkali granite exhibits an $\mathrm{AR}$ of 2.58-9.02. On the $\mathrm{AR}-\mathrm{SiO}_{2}$ diagram (Figure 4c), the rock samples were projected into the alkaline rock zone, except for a few that fall within the strongly alkaline rock zone. Hence, the rocks in this complex are alkaline rocks.

The trace element analysis of the Chishan alkaline complex indicated that the rocks are rich in large ion lithophile elements (LILEs) $\mathrm{Ba}$, $\mathrm{Sr}$, and $\mathrm{Rb}$ but poor in high field-strength elements (HFSEs) $\mathrm{Nb}$, $\mathrm{Ta}$, and Hf. The primitive mantle-normalized spidergram (Figure $5 \mathrm{~b}$ ) indicates a similarly incompatible element distribution pattern between the quartz syenite and alkaline granite of the Chishan alkaline complex. Both minerals exhibit remarkable positive $\mathrm{k}$ anomalies, strong negative $\mathrm{Sr}$ and $\mathrm{Ti}$ anomalies, and positive $\mathrm{Ba}$ and $\mathrm{Zr}$ anomalies.

The Chishan alkaline complex features a high total REE ( $\sum$ REE) value, with the quartz syenite featuring an average $\sum$ REE value of $692.18 \times 10^{-6}$ and the alkali granite yielding an average $\sum$ REE of $247.61 \times 10^{-6}$. The complex is extremely rich in LREEs. The LREE/HREE ratio ranges from 11.00 to 51.17 with an average of 29.88 . The $(\mathrm{La} / \mathrm{Yb})_{\mathrm{N}}$ value is $13.70-231.51$; the $\delta \mathrm{Eu}$ value is $0.84-1.24$, exhibiting a negative Eu anomaly. The $\delta C$ e value is $1.01-1.23$, exhibiting an unremarkable Ce anomaly. On the chondrite-normalized REE diagram (Figure 5a), the REE curve displays a visible right-inclined separation, showing a strong LREE enrichment. The rocks are poor in HREEs (heavy rare earth elements) and display appreciable LREE/HREE fractionation. This finding suggests that the rocks have experienced strong LREE/HREE fractionation and are highly rich in LREEs. 


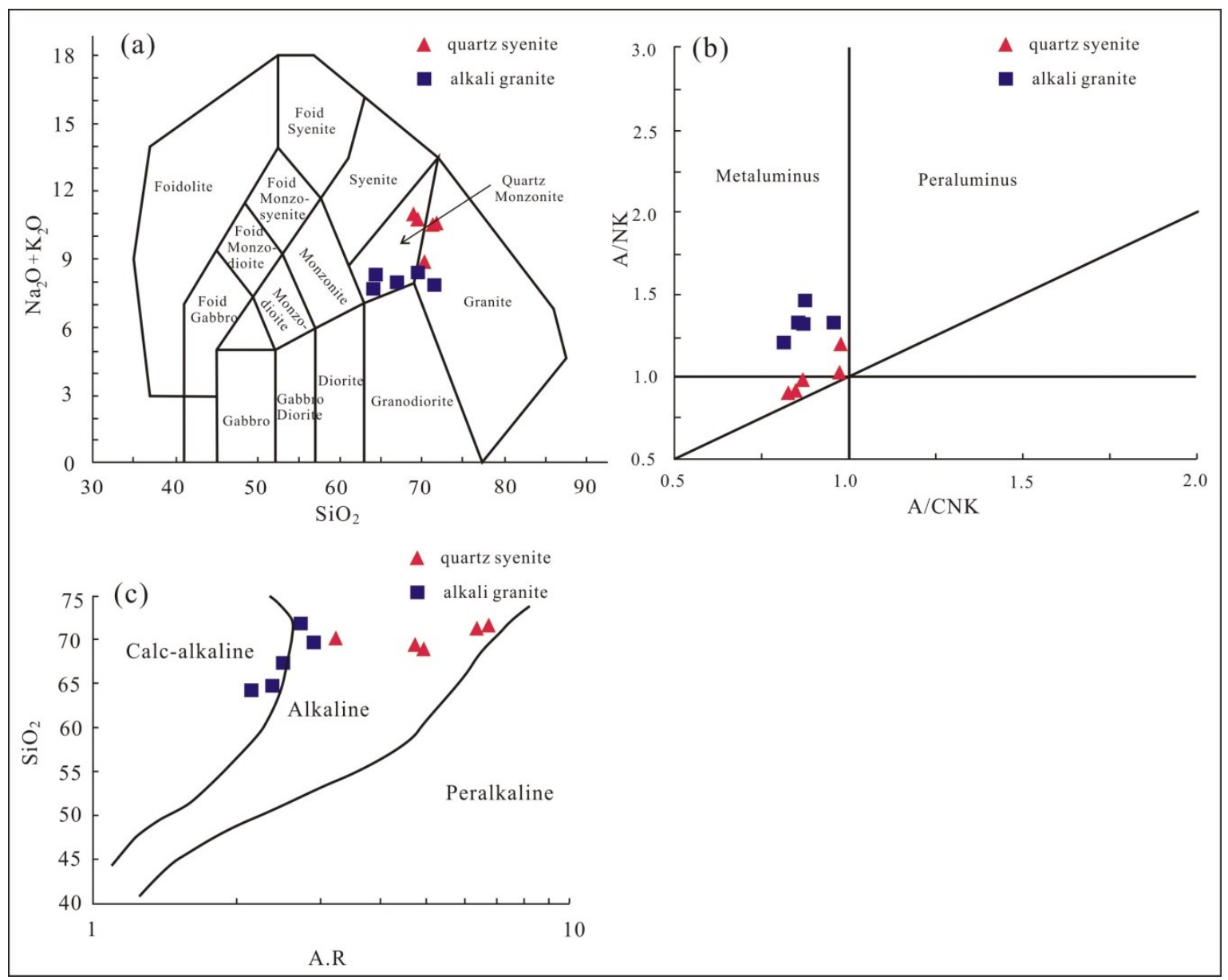

Figure 4. Plots of $\mathrm{SiO}_{2}$ vs. $\mathrm{Na}_{2} \mathrm{O}+\mathrm{K}_{2} \mathrm{O}(\mathbf{a}), \mathrm{A} / \mathrm{NK}$ (molar ratio $\mathrm{Al}_{2} \mathrm{O}_{3} /\left(\mathrm{Na}_{2} \mathrm{O}+\mathrm{K}_{2} \mathrm{O}\right)$ ) vs. $\mathrm{A} / \mathrm{CNK}$ (molar ratio $\left.\mathrm{Al}_{2} \mathrm{O}_{3} /\left(\mathrm{CaO}+\mathrm{Na}_{2} \mathrm{O}+\mathrm{K}_{2} \mathrm{O}\right)\right)(\mathbf{b})$, and $\mathrm{SiO}_{2}$ vs. A.R $\left(\mathrm{Al}_{2} \mathrm{O}_{3}+\mathrm{CaO}+\left(\mathrm{Na}_{2} \mathrm{O}+\mathrm{K}_{2} \mathrm{O}\right)\right) /\left(\mathrm{Al}_{2} \mathrm{O}_{3}+\mathrm{CaO}-\left(\mathrm{Na}_{2} \mathrm{O}\right.\right.$ $\left.+\mathrm{K}_{2} \mathrm{O}\right)$ ) (c) of the Chishan alkalic complex. (a) is from [56], (b) is from [57], and (c) is from [58]. 

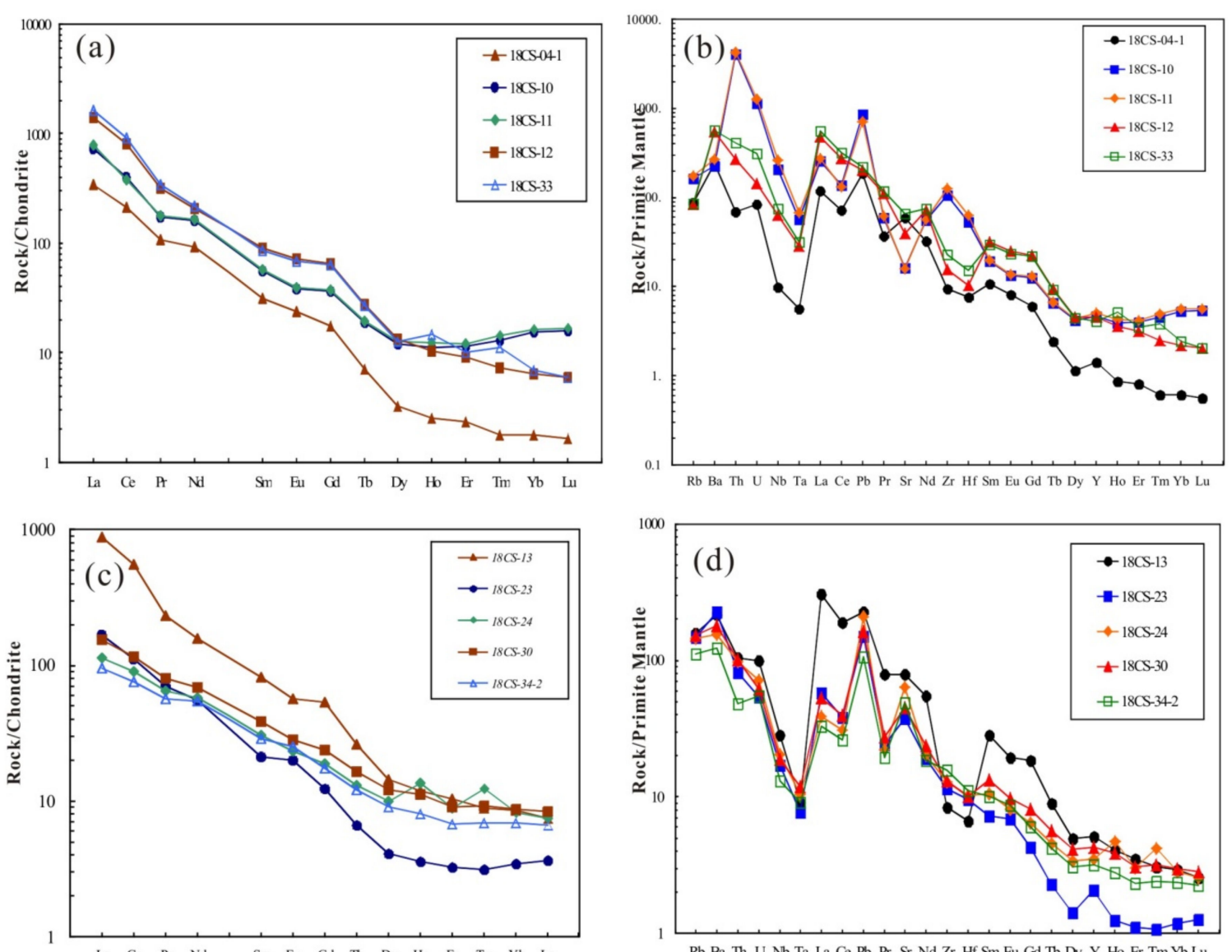

Figure 5. Chondrite-normalized REE patterns and primitive mantle (PM) normalized trace element spider diagram for quartz syenites $(\mathbf{a}, \mathbf{b})$ and alkali granites $(\mathbf{c}, \mathbf{d})$ from the Chishan alkalic complex (chondrite and PM values are from [59]). 
Table 1. Analysis results of the major (wt \%) and trace (ppm) elements of the Chishan alkaline complex.

\begin{tabular}{|c|c|c|c|c|c|c|c|c|c|c|}
\hline Samples & 18CS-04-1 & $18 C S-10$ & 18CS-11 & $18 \mathrm{CS}-12$ & $18 C S-33$ & $18 \mathrm{CS}-13$ & $18 C S-23$ & $18 C S-24$ & $18 C S-30$ & $18 C S-34-2$ \\
\hline & \multicolumn{5}{|c|}{ quartz syenite } & \multicolumn{5}{|c|}{ alkali granite } \\
\hline $\mathrm{SiO}_{2}$ & 70.20 & 71.35 & 71.72 & 69.02 & 69.42 & 69.55 & 71.66 & 64.44 & 67.13 & 64.07 \\
\hline $\mathrm{Al}_{2} \mathrm{O}_{3}$ & 15.25 & 13.74 & 13.51 & 16.12 & 15.41 & 14.07 & 14.70 & 16.50 & 15.09 & 16.75 \\
\hline $\mathrm{MgO}$ & 0.49 & 0.16 & 0.19 & 0.15 & 0.48 & 0.62 & 0.71 & 1.39 & 1.33 & 1.55 \\
\hline $\mathrm{Na}_{2} \mathrm{O}$ & 5.53 & 6.25 & 6.12 & 7.13 & 7.11 & 4.76 & 4.64 & 6.20 & 4.99 & 5.91 \\
\hline $\mathrm{K}_{2} \mathrm{O}$ & 3.34 & 4.29 & 4.43 & 3.82 & 3.67 & 3.59 & 3.20 & 2.08 & 2.95 & 1.70 \\
\hline $\mathrm{P}_{2} \mathrm{O}_{5}$ & 0.07 & 0.03 & 0.04 & 0.10 & 0.11 & 0.09 & 0.09 & 0.18 & 0.11 & 0.20 \\
\hline $\mathrm{TiO}_{2}$ & 0.17 & 0.08 & 0.06 & 0.11 & 0.11 & 0.19 & 0.19 & 0.36 & 0.32 & 0.40 \\
\hline $\mathrm{CaO}$ & 1.59 & 0.73 & 0.74 & 0.38 & 1.15 & 3.03 & 2.32 & 3.78 & 3.32 & 4.14 \\
\hline $\mathrm{TFe}_{2} \mathrm{O}_{3}$ & 1.32 & 2.35 & 2.31 & 1.38 & 1.50 & 1.74 & 1.93 & 3.75 & 3.19 & 4.19 \\
\hline $\mathrm{FeO}$ & 0.76 & 0.39 & 0.39 & 0.12 & 0.37 & 0.89 & 1.08 & 1.70 & 1.50 & 1.83 \\
\hline $\mathrm{Fe}_{2} \mathrm{O}_{3}$ & 0.48 & 1.92 & 1.87 & 1.25 & 1.09 & 0.76 & 0.73 & 1.87 & 1.52 & 2.16 \\
\hline $\mathrm{MnO}$ & 0.02 & 0.13 & 0.12 & 0.05 & 0.05 & 0.09 & 0.04 & 0.08 & 0.07 & 0.07 \\
\hline LOI & 2.45 & 0.77 & 0.71 & 0.96 & 0.63 & 2.00 & 0.68 & 1.36 & 1.60 & 1.17 \\
\hline Total & 100.43 & 99.87 & 99.94 & 99.21 & 99.65 & 99.73 & 100.15 & 100.13 & 100.10 & 100.14 \\
\hline $\mathrm{Na}_{2} \mathrm{O}+\mathrm{K}_{2} \mathrm{O}$ & 8.87 & 10.53 & 10.56 & 10.94 & 10.78 & 8.35 & 7.84 & 8.28 & 7.94 & 7.62 \\
\hline $\mathrm{A} / \mathrm{NK}$ & 1.199 & 0.921 & 0.908 & 1.017 & 0.983 & 1.2 & 1.325 & 1.325 & 1.324 & 1.447 \\
\hline $\mathrm{A} / \mathrm{CNK}$ & 0.977 & 0.846 & 0.833 & 0.974 & 0.867 & 0.816 & 0.96 & 0.854 & 0.865 & 0.877 \\
\hline AR & 3.23 & 6.36 & 6.73 & 4.94 & 4.73 & 2.91 & 2.71 & 2.38 & 2.51 & 2.15 \\
\hline $\mathrm{Rb}$ & 54.93 & 102.57 & 109.93 & 52.93 & 54.15 & 103.24 & 94.02 & 92.16 & 97.01 & 71.09 \\
\hline $\mathrm{Sr}$ & 1235.82 & 339.67 & 337.60 & 830.67 & 1381.18 & 1670.70 & 793.43 & 1354.19 & 945.03 & 1027.48 \\
\hline $\mathrm{Ba}$ & 1694.82 & 1572.33 & 1866.33 & 3825.37 & 3975.62 & 1539.17 & 1572.63 & 1075.93 & 1245.54 & 856.73 \\
\hline Th & 5.80 & 342.33 & 362.58 & 23.00 & 34.86 & 9.64 & 6.94 & 8.37 & 8.63 & 4.06 \\
\hline $\mathrm{U}$ & 1.77 & 23.87 & 26.92 & 2.99 & 6.55 & 1.87 & 1.13 & 1.50 & 1.30 & 1.16 \\
\hline $\mathrm{Nb}$ & 7.09 & 148.94 & 187.67 & 44.96 & 53.76 & 17.12 & 12.23 & 14.60 & 13.35 & 9.38 \\
\hline $\mathrm{Ta}$ & 0.23 & 2.30 & 2.75 & 1.16 & 1.29 & 0.39 & 0.32 & 0.43 & 0.49 & 0.37 \\
\hline $\mathrm{Zr}$ & 106.19 & 1196.82 & 1413.12 & 175.74 & 255.58 & 87.80 & 128.83 & 143.37 & 146.91 & 174.67 \\
\hline $\mathrm{Hf}$ & 2.35 & 16.56 & 19.43 & 3.16 & 4.67 & 1.96 & 2.97 & 3.16 & 3.09 & 3.46 \\
\hline Co & 4.62 & 1.82 & 1.32 & 2.35 & 3.45 & 5.59 & 6.43 & 12.59 & 13.08 & 16.41 \\
\hline $\mathrm{Ni}$ & 3.27 & 14.14 & 1.99 & 4.01 & 9.86 & 4.79 & 4.83 & 12.95 & 14.50 & 13.17 \\
\hline $\mathrm{Cr}$ & 12.69 & 29.35 & 10.00 & 18.35 & 19.12 & 12.65 & 11.27 & 13.84 & 25.16 & 13.75 \\
\hline $\mathrm{V}$ & 23.75 & 32.94 & 31.11 & 25.39 & 27.36 & 29.32 & 34.95 & 57.90 & 52.34 & 78.94 \\
\hline Sc & 7.15 & 6.38 & 6.99 & 8.74 & 7.85 & 6.58 & 5.80 & 9.76 & 13.28 & 16.56 \\
\hline Cs & 0.91 & 0.27 & 0.32 & 0.18 & 0.22 & 1.65 & 1.78 & 2.86 & 2.25 & 2.23 \\
\hline
\end{tabular}


Table 1. Cont

\begin{tabular}{|c|c|c|c|c|c|c|c|c|c|c|}
\hline Samples & 18CS-04-1 & $18 C S-10$ & $18 C S-11$ & 18CS-12 & $18 C S-33$ & $18 \mathrm{CS}-13$ & $18 \mathrm{CS}-23$ & 18CS-24 & $18 C S-30$ & $18 C S-34-2$ \\
\hline $\mathrm{Ga}$ & 58.10 & 60.66 & 61.71 & 67.52 & 46.97 & 55.99 & 45.02 & 59.30 & 50.84 & 58.69 \\
\hline $\mathrm{Cu}$ & 9.62 & 8.52 & 8.03 & 6.73 & 5.69 & 10.58 & 5.18 & 7.36 & 45.68 & 21.13 \\
\hline $\mathrm{Pb}$ & 13.27 & 61.06 & 50.37 & 14.47 & 15.78 & 14.20 & 10.64 & 14.83 & 11.47 & 7.55 \\
\hline $\mathrm{Zn}$ & 36.49 & 99.67 & 104.08 & 37.83 & 73.80 & 41.55 & 35.42 & 65.29 & 60.14 & 64.96 \\
\hline $\mathrm{Be}$ & 2.30 & 17.92 & 18.15 & 3.89 & 4.89 & 1.98 & 1.90 & 2.37 & 2.34 & 2.12 \\
\hline $\mathrm{La}$ & 81.50 & 174.62 & 187.46 & 330.85 & 383.69 & 219.65 & 39.33 & 26.67 & 36.75 & 22.78 \\
\hline $\mathrm{Ce}$ & 128.85 & 244.16 & 231.99 & 489.15 & 560.84 & 347.44 & 67.59 & 54.80 & 70.24 & 46.35 \\
\hline $\operatorname{Pr}$ & 10.20 & 16.42 & 16.97 & 30.48 & 32.84 & 22.83 & 6.62 & 6.13 & 7.57 & 5.41 \\
\hline $\mathrm{Nd}$ & 43.37 & 74.72 & 76.91 & 97.28 & 101.77 & 77.68 & 25.97 & 27.17 & 32.22 & 25.25 \\
\hline Sm & 4.78 & 8.64 & 8.78 & 13.91 & 13.26 & 13.28 & 3.22 & 4.66 & 5.93 & 4.44 \\
\hline $\mathrm{Eu}$ & 1.38 & 2.23 & 2.29 & 4.15 & 3.94 & 3.46 & 1.16 & 1.36 & 1.64 & 1.45 \\
\hline $\mathrm{Gd}$ & 3.58 & 7.52 & 7.73 & 13.43 & 13.04 & 11.43 & 2.53 & 3.85 & 4.85 & 3.58 \\
\hline $\mathrm{Tb}$ & 0.26 & 0.70 & 0.73 & 1.03 & 1.00 & 1.02 & 0.25 & 0.49 & 0.61 & 0.45 \\
\hline Dy & 0.83 & 3.08 & 3.21 & 3.36 & 3.25 & 3.84 & 1.05 & 2.51 & 3.06 & 2.28 \\
\hline Ho & 0.14 & 0.64 & 0.70 & 0.58 & 0.84 & 0.72 & 0.20 & 0.77 & 0.63 & 0.46 \\
\hline $\mathrm{Er}$ & 0.39 & 1.89 & 1.99 & 1.51 & 1.67 & 1.77 & 0.53 & 1.46 & 1.49 & 1.12 \\
\hline $\mathrm{Tm}$ & 0.04 & 0.33 & 0.36 & 0.18 & 0.28 & 0.24 & 0.08 & 0.31 & 0.24 & 0.18 \\
\hline $\mathrm{Yb}$ & 0.30 & 2.61 & 2.77 & 1.08 & 1.19 & 1.52 & 0.59 & 1.40 & 1.48 & 1.16 \\
\hline $\mathrm{Lu}$ & 0.04 & 0.40 & 0.42 & 0.15 & 0.15 & 0.20 & 0.09 & 0.19 & 0.21 & 0.17 \\
\hline $\mathrm{Y}$ & 6.44 & 21.15 & 22.93 & 20.51 & 18.35 & 24.60 & 9.42 & 15.97 & 19.39 & 14.44 \\
\hline$\sum$ REE & 275.68 & 537.98 & 542.32 & 987.16 & 1117.77 & 705.08 & 149.20 & 131.77 & 166.91 & 115.08 \\
\hline LREE/HREE & 18.11 & 19.12 & 17.56 & 21.40 & 17.17 & 18.14 & 5.04 & 2.70 & 7.21 & 2.95 \\
\hline $\mathrm{La}_{\mathrm{N}} / \mathrm{Yb}_{\mathrm{N}}$ & 31.99 & 41.74 & 35.56 & 31.51 & 23.52 & 38.04 & 3.33 & 1.59 & 5.73 & 1.73 \\
\hline$\delta \mathrm{Eu}$ & 1.36 & 1.56 & 2.30 & 1.35 & 2.53 & 1.28 & 0.93 & 2.35 & 7.37 & 1.42 \\
\hline
\end{tabular}




\subsection{Zircon $\mathrm{U}-\mathrm{Pb}$ Dating}

In the quartz syenite (18CS-01, Figure 6a), zircons exist as automorphic columns or stumps with a complete crystal form and smooth surface. Most of the zircons contain zonal texture, suggesting a magmatic origin. The zircon grains in the sample are large, with clear internal texture, well-arranged zones, and an aspect ratio of 1:1.5-1:5, which agrees with the description of a magmatic zircon. In the alkali granite (18CS-27, Figure 6b), the zircons are well automorphic, mostly columnar in shape with a complete crystal form and smooth surface, and vary in size from $30 \mu \mathrm{m}$ up to $100 \mu \mathrm{m}$. The zircons contain a clear visible zonal texture, whereas some zircon samples showed inherited zircon cores. The $\mathrm{Th} / \mathrm{U}$ values are unexceptionally greater than 0.4 . Almost all the zircon samples displayed the features typical of an alkaline magmatic zircon. Some of the zircons displayed a core-mantle texture, suggesting inherited growths. In the sample, the zircons feature relatively large grain sizes, clear internal texture, well-arranged zones, and an aspect ratio of 1:1.5-1:5, which agree with the description of a magmatic zircon. The measured $U$ and Th contents spanned broadly from $249 \times 10^{-6}$ to $2338 \times 10^{-6}$ and from $20 \times 10^{-6}$ to $133 \times 10^{-6}$, respectively; the measured $\mathrm{Th} / \mathrm{U}$ values ranged narrowly from 0.01 to 0.06 .
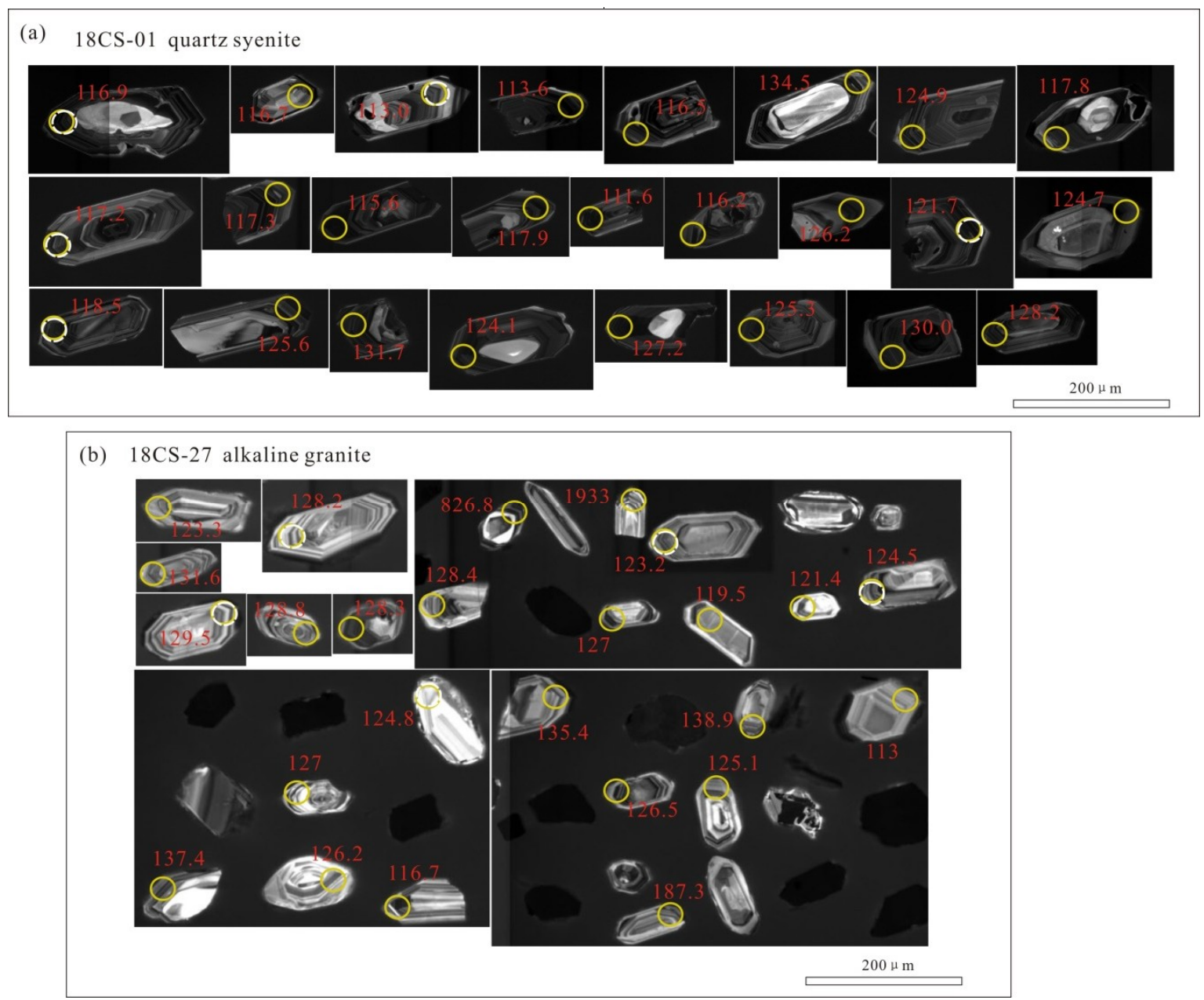

Figure 6. Zircon cathode luminescence (CL) diagram of the Chishan alkaline complex. (a) is the CL of quartz syenite (18CS-01); (b) is the CL of alkali granite (18CS-27).

Table 2 presents the valid data of the zircons in samples 18CS-01 and 18CS-27. The ${ }^{206} \mathrm{~Pb} /{ }^{238} \mathrm{U}-{ }^{207} \mathrm{~Pb} /{ }^{235} \mathrm{U}$ concordia curve projection was performed on 23 valid data of sample $18 \mathrm{CS}-01$ and 17 valid data of the magmatic zircons in sample $18 \mathrm{CS}-27$; the ${ }^{206} \mathrm{~Pb} /{ }^{238} \mathrm{U}$ ages were weighted averaged (Figure 7a-d). The results indicated a concordia age of $125.8 \pm 1.2 \mathrm{Ma}(\mathrm{MSWD}=1.4)$ for zircons 
in the quartz syenite and $127.3 \pm 1.0 \mathrm{Ma}(\mathrm{MSWD}=1.13)$ for zircons in the alkali granite of the Chishan alkaline complex.

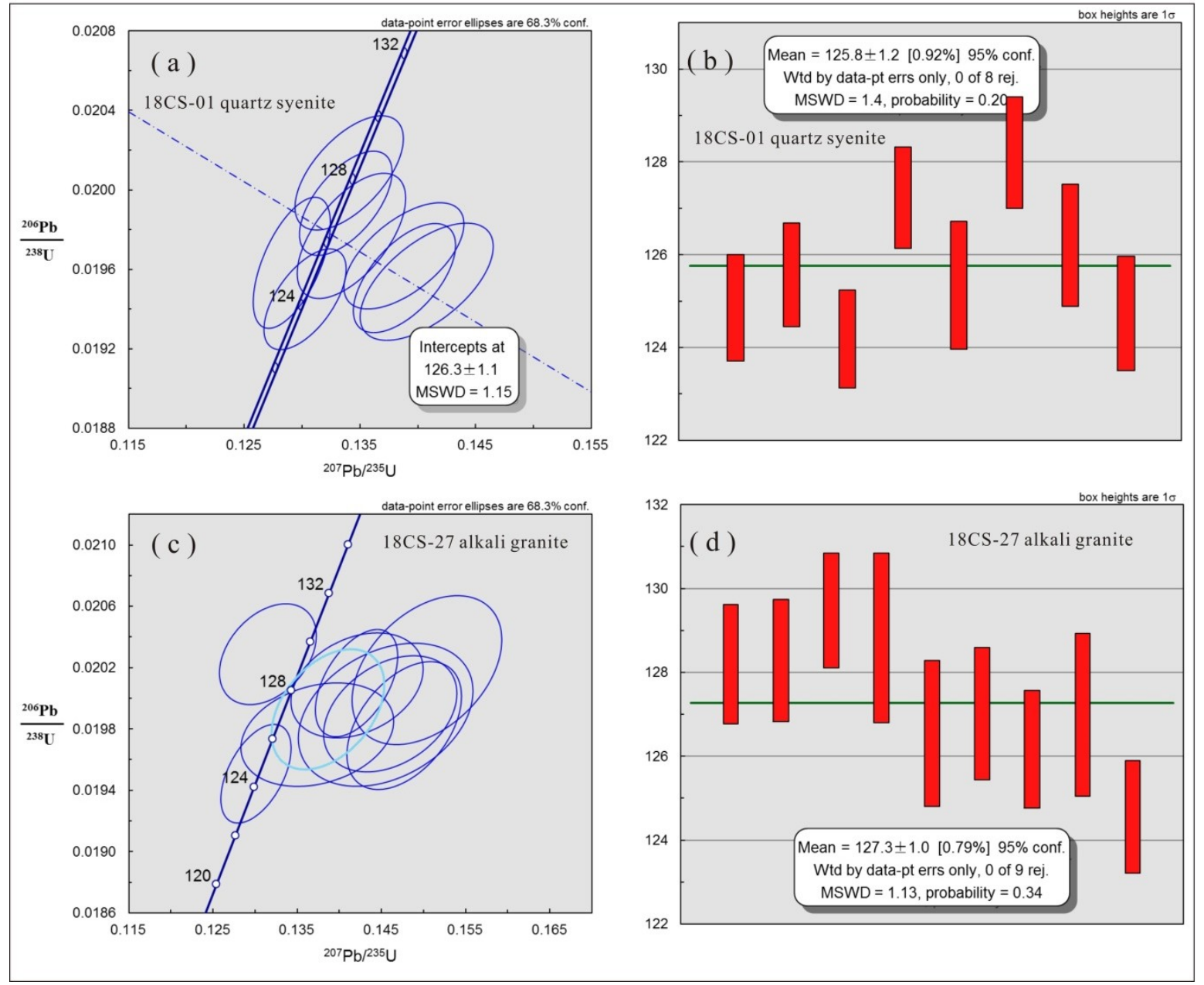

Figure 7. Zircon $\mathrm{U}-\mathrm{Pb}$ age concordia plot of the Chishan alkaline complex. (a) is the concordia plot of quartz syenite (18CS-01); (b) is the average plot of quartz syenite (18CS-01); (c) is the concordia plot of alkali granite (18CS-27); (d) is the average plot of alkali granite (18CS-27).

\subsection{Zircon Lu-Hf Dating}

In situ Hf isotope analysis was conducted on five already-dated zircon samples from the quartz syenite and from the alkali granite, respectively, at roughly the same points as those used for zircon $\mathrm{U}-\mathrm{Pb}$ dating. Table 3 presents the results. Then, the initial ratios and $\varepsilon \mathrm{Hf}(\mathrm{t})$ values of zircon $\mathrm{Hf}$ isotopes were calculated with the measured ages. From Table 3, the ${ }^{176} \mathrm{Lu} /{ }^{177} \mathrm{Hf}$ ratios were smaller than 0.002 at all points, suggesting that the zircons have gained no considerable radiogenic Hf after the complex formation. Consequently, the zircon ${ }^{176} \mathrm{Hf} /{ }^{177} \mathrm{Hf}$ ratios can be used to discuss the genetic information of the complex [55]. As the zircons in the samples show low $f_{\mathrm{Lu} / \mathrm{Hf}}$ ratios $(-0.95--0.98)$, the one-stage model ages of the zircon $\mathrm{Lu}-\mathrm{Hf}$ isotopes can represent the time at which the source materials separated from the mantle [60]. Zircons from the quartz syenite (18CS-01) have variable ${ }^{176} \mathrm{Hf} /{ }^{177} \mathrm{Hf}$ ratios $(0.28225-0.28232)$ with $\varepsilon \mathrm{Hf}(\mathrm{t})$ values ranging from -13.2 to -15.8 . Their depleted model ages $\left(\mathrm{T}_{\mathrm{DM}}\right)$ range from $1296 \mathrm{Ma}$ to $1359 \mathrm{Ma}$ and crustal model ages $\left(\mathrm{T}_{\mathrm{DM}}{ }^{\mathrm{C}}\right)$ from $2074 \mathrm{Ma}$ to $2186 \mathrm{Ma}$. Zircons from the alkali syenite (18CS-27) have relatively low and variable ${ }^{176} \mathrm{Hf} /{ }^{177} \mathrm{Hf}$ ratios $(0.28206-0.28232)$ with $\varepsilon \mathrm{Hf}(\mathrm{t})$ values ranging from -13.4 to -22.7 , depleted model ages $\left(\mathrm{T}_{\mathrm{DM}}\right)$ ranging from $1324 \mathrm{Ma}$ to $1675 \mathrm{Ma}$ and crustal model ages $\left(\mathrm{T}_{\mathrm{DM}}{ }^{\mathrm{C}}\right)$ of 2036-2617 Ma. 
Table 2. Zircon $\mathrm{U}-\mathrm{Pb}$ dating data of the Chishan alkaline complex.

\begin{tabular}{|c|c|c|c|c|c|c|c|c|c|c|c|c|c|c|c|c|c|}
\hline \multirow{2}{*}{ Samples } & \multicolumn{3}{|c|}{ Content $\left(10^{-6}\right)$} & \multirow{2}{*}{${ }^{232} \mathrm{Th} /{ }^{238} \mathrm{U}$} & \multicolumn{6}{|c|}{ Ratio/1sigma } & \multicolumn{6}{|c|}{ Age(Ma)/1sigma } & \multirow{2}{*}{ Concord-Ance } \\
\hline & $\mathrm{Th}^{232}$ & $\mathrm{U}^{238}$ & $\mathrm{~Pb}$ & & ${ }^{207} \mathrm{~Pb} /{ }^{206} \mathrm{~Pb}$ & $(1 \sigma)$ & ${ }^{207} \mathrm{~Pb} /{ }^{235} \mathrm{U}$ & $(1 \sigma)$ & ${ }^{206} \mathrm{~Pb} /{ }^{238} \mathrm{U}$ & (1б) & ${ }^{207} \mathrm{~Pb} /{ }^{206} \mathrm{~Pb}$ & $(1 \sigma)$ & ${ }^{207} \mathrm{~Pb} /{ }^{235} \mathrm{U}$ & $(1 \sigma)$ & ${ }^{206} \mathrm{~Pb} /{ }^{238} \mathrm{U}$ & $(1 \sigma)$ & \\
\hline 18CS-01-01 & 472.266 & 1574.096 & 72.42149 & 0.013808 & 0.047655 & 0.0008 & 0.120187 & 0.001995 & 0.018313 & 0.000146 & 83.425 & 42.5875 & 115.2415 & 1.807961 & 116.9831 & 0.926284 & $98 \%$ \\
\hline 18CS-01-02 & 141.3717 & 484.5583 & 22.00171 & 0.045451 & 0.048555 & 0.0015 & 0.121936 & 0.00375 & 0.018278 & 0.00019 & 127.865 & 77.7675 & 116.8258 & 3.394018 & 116.7661 & 1.200294 & $99 \%$ \\
\hline 18 CS- $01-03$ & 112.2566 & 536.1725 & 19.61299 & 0.050986 & 0.049164 & 0.0013 & 0.119702 & 0.00321 & 0.017678 & 0.000192 & 166.75 & 60.175 & 114.8018 & 2.911336 & 112.9642 & 1.216271 & $98 \%$ \\
\hline 18CS-01-04 & 899.1592 & 2338.122 & 124.8586 & 0.008009 & 0.050982 & 0.0008 & 0.124976 & 0.00207 & 0.017779 & 0.000154 & 238.955 & 32.4025 & 119.5729 & 1.868731 & 113.6043 & 0.977245 & $94 \%$ \\
\hline 18CS-01-05 & 356.5362 & 1040.718 & 54.79529 & 0.018249 & 0.052719 & 0.0016 & 0.132715 & 0.004329 & 0.018234 & 0.000151 & 316.725 & 72.215 & 126.5343 & 3.880344 & 116.484 & 0.958009 & $91 \%$ \\
\hline 18CS-01-06 & 472.2965 & 1369.869 & 85.68922 & 0.011670 & 0.064813 & 0.0010 & 0.188885 & 0.003809 & 0.021084 & 0.000231 & 768.52 & 227.775 & 175.6776 & 3.252768 & 134.5061 & 1.460831 & $73 \%$ \\
\hline 18CS-01-07 & 319.7484 & 1300.715 & 55.01009 & 0.018178 & 0.050943 & 0.0010 & 0.129436 & 0.002559 & 0.018442 & 0.000168 & 238.955 & 46.2875 & 123.5911 & 2.300364 & 117.8035 & 1.064738 & $95 \%$ \\
\hline 18CS-01-08 & 318.2334 & 745.503 & 40.82856 & 0.024492 & 0.049643 & 0.0011 & 0.125423 & 0.00292 & 0.018346 & 0.000172 & 188.97 & 53.695 & 119.977 & 2.634657 & 117.1929 & 1.088303 & $97 \%$ \\
\hline 18CS-01-09 & 456.0166 & 1273.565 & 63.5378 & 0.015738 & 0.047779 & 0.0007 & 0.121213 & 0.002327 & 0.018359 & 0.000169 & 87.13 & 37.0325 & 116.1708 & 2.107511 & 117.278 & 1.069839 & $99 \%$ \\
\hline 18CS-01-10 & 1128.152 & 1975.129 & 133.8668 & 0.007470 & 0.053944 & 0.0008 & 0.134592 & 0.002222 & 0.01809 & 0.000142 & 368.57 & 67.585 & 128.2157 & 1.988704 & 115.5733 & 0.898444 & $89 \%$ \\
\hline 18CS-01-11 & 651.9653 & 1577.681 & 86.08203 & 0.011616 & 0.04734 & 0.0008 & 0.120433 & 0.002483 & 0.018459 & 0.000219 & 64.91 & 44.44 & 115.4646 & 2.249844 & 117.9099 & 1.387347 & $97 \%$ \\
\hline 18CS-01-12 & 898.3659 & 2328.23 & 124.3088 & 0.008044 & 0.053159 & 0.0012 & 0.128194 & 0.003227 & 0.01747 & 0.000168 & 344.5 & 51.8475 & 122.4733 & 2.904556 & 111.6455 & 1.061992 & $90 \%$ \\
\hline 18CS-01-13 & 788.5011 & 1671.612 & 103.3689 & 0.009674 & 0.050465 & 0.0009 & 0.132032 & 0.002546 & 0.019059 & 0.000271 & 216.74 & 44.435 & 125.922 & 2.283971 & 121.7033 & 1.71218 & $96 \%$ \\
\hline 18CS-01-14 & 457.0531 & 1327.671 & 73.53172 & 0.013599 & 0.0583 & 0.0013 & 0.14635 & 0.003806 & 0.018185 & 0.000228 & 542.63 & 45.365 & 138.6842 & 3.371065 & 116.1738 & 1.443957 & $82 \%$ \\
\hline 18CS-01-15 & 586.9446 & 1444.842 & 83.7469 & 0.011940 & 0.051583 & 0.0011 & 0.138845 & 0.002916 & 0.019556 & 0.000181 & 333.39 & 53.6975 & 132.0148 & 2.599895 & 124.8503 & 1.146076 & $94 \%$ \\
\hline 18CS-01-16 & 1575.995 & 1557.102 & 167.3218 & 0.005976 & 0.052591 & 0.0011 & 0.134521 & 0.00305 & 0.018556 & 0.000209 & 322.28 & 52.7725 & 128.1519 & 2.729537 & 118.5211 & 1.322501 & $92 \%$ \\
\hline 18CS-01-17 & 332.9182 & 1256.546 & 57.44716 & 0.017407 & 0.051117 & 0.0011 & 0.138803 & 0.003422 & 0.019668 & 0.000177 & 255.62 & 53.695 & 131.9771 & 3.05101 & 125.558 & 1.116436 & $95 \%$ \\
\hline 18CS-01-18 & 228.5987 & 1247.068 & 48.28645 & 0.020709 & 0.048046 & 0.0008 & 0.136866 & 0.002847 & 0.020647 & 0.000245 & 101.94 & 42.59 & 130.249 & 2.542711 & 131.7423 & 1.54961 & $98 \%$ \\
\hline 18CS-01-19 & 823.7941 & 1948.765 & 108.8157 & 0.009189 & 0.048503 & 0.0007 & 0.130254 & 0.002346 & 0.019449 & 0.000167 & 124.16 & 37.0325 & 124.3262 & 2.107497 & 124.1746 & 1.058586 & $99 \%$ \\
\hline 18CS-01-20 & 660.8823 & 1571.493 & 90.21077 & 0.011085 & 0.048625 & 0.0008 & 0.133771 & 0.002641 & 0.019933 & 0.000173 & 131.57 & 42.5875 & 127.4804 & 2.365375 & 127.2304 & 1.094315 & $99 \%$ \\
\hline 18CS-01-21 & 420.7892 & 1471.985 & 65.17453 & 0.015343 & 0.047701 & 0.0007 & 0.129111 & 0.002201 & 0.019633 & 0.000218 & 83.425 & 32.405 & 123.2988 & 1.97913 & 125.3364 & 1.377201 & $98 \%$ \\
\hline 18CS-01-22 & 156.5514 & 737.5803 & 28.84884 & 0.034663 & 0.049044 & 0.0011 & 0.137333 & 0.003077 & 0.02037 & 0.000237 & 150.085 & 58.325 & 130.6653 & 2.74676 & 129.9958 & 1.496093 & $99 \%$ \\
\hline 18CS-01-23 & 278.1643 & 755.6438 & 39.65799 & 0.025215 & 0.048441 & 0.0010 & 0.134069 & 0.003091 & 0.020085 & 0.00019 & 120.46 & 47.2175 & 127.7476 & 2.767645 & 128.1955 & 1.199058 & $99 \%$ \\
\hline 18CS-01-24 & 431.8319 & 1024.951 & 53.68663 & 0.018626 & 0.049214 & 0.0010 & 0.134265 & 0.003093 & 0.019769 & 0.000208 & 166.75 & 48.14 & 127.9231 & 2.768721 & 126.1937 & 1.315243 & $98 \%$ \\
\hline 18CS-01-25 & 542.2902 & 1066.892 & 70.0304 & 0.014279 & 0.052021 & 0.0011 & 0.140767 & 0.003797 & 0.019538 & 0.000195 & 287.1 & 54.625 & 133.7268 & 3.379782 & 124.7336 & 1.231627 & $93 \%$ \\
\hline 18CS-27-01 & 417.35 & 574.775 & 50.98 & 0.01962 & 0.0529 & 0.0015 & 0.1409 & 0.004 & 0.0193 & 0.0002 & 324.13 & 62.96 & 133.83 & 3.4989 & 123.3 & 1.0768 & $91 \%$ \\
\hline 18 CS-27-02 & 206.17 & 391.128 & 28.38 & 0.03524 & 0.0512 & 0.0016 & 0.1421 & 0.005 & 0.02008 & 0.0002 & 255.62 & 74.06 & 134.91 & 4.6077 & 128.2 & 1.4283 & $94 \%$ \\
\hline $18 \mathrm{CS}-27-03$ & 401.89 & 638.972 & 101 & 0.0099 & 0.1234 & 0.004 & 0.3537 & 0.013 & 0.02063 & 0.0002 & 2005.3 & 58.02 & 307.52 & 9.8711 & 131.6 & 1.3585 & $19 \%$ \\
\hline 18CS-27-04 & 1575.8 & 989.838 & 173.7 & 0.00576 & 0.0512 & 0.001 & 0.142 & 0.003 & 0.0201 & 0.0002 & 250.07 & 43.51 & 134.86 & 2.8708 & 128.3 & 1.4591 & $94 \%$ \\
\hline 18CS-27-05 & 280.19 & 391.704 & 37.03 & 0.027 & 0.0471 & 0.0014 & 0.1315 & 0.004 & 0.02029 & 0.0002 & 53.8 & 66.66 & 125.46 & 3.4071 & 129.5 & 1.3713 & $96 \%$ \\
\hline 18CS-27-06 & 686.96 & 449.545 & 74.51 & 0.01342 & 0.0541 & 0.002 & 0.1504 & 0.006 & 0.02018 & 0.0003 & 375.98 & 85.18 & 142.27 & 5.1808 & 128.8 & 2.026 & $90 \%$ \\
\hline 18CS-27-07 & 147.02 & 323.972 & 21.98 & 0.0455 & 0.0539 & 0.0025 & 0.1567 & 0.007 & 0.02123 & 0.0003 & 364.87 & 110.2 & 147.84 & 5.9398 & 135.4 & 1.7638 & $91 \%$ \\
\hline 18CS-27-08 & 406.1 & 671.044 & 56.57 & 0.01768 & 0.0542 & 0.0018 & 0.1477 & 0.004 & 0.01982 & 0.0003 & 388.94 & 75.92 & 139.88 & 3.9736 & 126.5 & 1.7396 & $89 \%$ \\
\hline 18CS-27-09 & 708.24 & 531.91 & 321.2 & 0.00311 & 0.3259 & 0.0103 & 1.3329 & 0.067 & 0.02948 & 0.0008 & 3598.1 & 48.22 & 860.14 & 29.004 & 187.3 & 4.9803 & $-29 \%$ \\
\hline $18 \mathrm{CS}-27-10$ & 497.94 & 520.623 & 65.74 & 0.01521 & 0.0583 & 0.0022 & 0.1574 & 0.006 & 0.0196 & 0.0002 & 542.63 & 83.32 & 148.41 & 5.2574 & 125.1 & 1.4374 & $82 \%$ \\
\hline 18CS-27-11 & 495.14 & 480.37 & 92 & 0.01087 & 0.1088 & 0.0038 & 0.3258 & 0.011 & 0.02177 & 0.0003 & 1788.9 & 64.51 & 286.38 & 8.7345 & 138.9 & 1.5795 & $30 \%$ \\
\hline 18CS-27-12 & 344.03 & 316.666 & 36.02 & 0.02776 & 0.053 & 0.0023 & 0.1289 & 0.006 & 0.01769 & 0.0002 & 327.84 & 99.99 & 123.07 & 5.0352 & 113 & 1.1601 & $91 \%$ \\
\hline
\end{tabular}


Table 2. Cont.

\begin{tabular}{|c|c|c|c|c|c|c|c|c|c|c|c|c|c|c|c|c|c|}
\hline \multirow{2}{*}{ Samples } & \multicolumn{3}{|c|}{ Content $\left(10^{-6}\right)$} & \multirow{2}{*}{${ }^{232} \mathrm{Th} /{ }^{238} \mathrm{U}$} & \multicolumn{6}{|c|}{ Ratio/1sigma } & \multicolumn{6}{|c|}{ Age(Ma)/1sigma } & \multirow{2}{*}{ Concord-Ance } \\
\hline & $\mathrm{Th}^{232}$ & $\mathrm{U}^{238}$ & $\mathbf{P b}$ & & ${ }^{207} \mathrm{~Pb} /{ }^{206} \mathrm{~Pb}$ & $(1 \sigma)$ & ${ }^{207} \mathrm{~Pb} /{ }^{235} \mathrm{U}$ & $(1 \sigma)$ & ${ }^{206} \mathrm{~Pb} /{ }^{38} \mathrm{U}$ & $(1 \sigma)$ & ${ }^{207} \mathrm{~Pb} /{ }^{206} \mathrm{~Pb}$ & $(1 \sigma)$ & ${ }^{207} \mathrm{~Pb} /{ }^{235} \mathrm{U}$ & $(1 \sigma)$ & ${ }^{206} \mathrm{~Pb} /{ }^{238} \mathrm{U}$ & $(1 \sigma)$ & \\
\hline $18 \mathrm{CS}-27-13$ & 403.35 & 361.82 & 52.96 & 0.01888 & 0.0542 & 0.002 & 0.1606 & 0.006 & 0.02155 & 0.0003 & 388.94 & 81.47 & 151.21 & 4.9154 & 137.4 & 1.7486 & $90 \%$ \\
\hline $18 \mathrm{CS}-27-14$ & 329.94 & 493.923 & 39.33 & 0.02542 & 0.0531 & 0.0018 & 0.146 & 0.005 & 0.0199 & 0.0003 & 344.5 & 74.07 & 138.41 & 4.6296 & 127 & 1.5806 & $91 \%$ \\
\hline 18CS-27-15 & 187.46 & 249.474 & 183.4 & 0.00545 & 0.0736 & 0.0012 & 1.6201 & 0.025 & 0.15983 & 0.0015 & 1031.5 & 31.95 & 978.03 & 9.6871 & 955.8 & 8.5274 & $97 \%$ \\
\hline 18CS-27-16 & 549.1 & 370.138 & 60.88 & 0.01643 & 0.0504 & 0.0021 & 0.1374 & 0.006 & 0.01976 & 0.0002 & 213.04 & 91.65 & 130.71 & 5.3468 & 126.2 & 1.4083 & $96 \%$ \\
\hline 18CS-27-17 & 234.19 & 784.505 & 35.75 & 0.02798 & 0.0493 & 0.0014 & 0.1238 & 0.003 & 0.01827 & 0.0002 & 161.2 & 66.66 & 118.49 & 3.1387 & 116.7 & 1.1585 & $98 \%$ \\
\hline $18 \mathrm{CS}-27-18$ & 391.19 & 527.786 & 54.24 & 0.01844 & 0.0569 & 0.0016 & 0.1581 & 0.005 & 0.02012 & 0.0003 & 487.08 & 58.33 & 149 & 4.3331 & 128.4 & 1.6889 & $85 \%$ \\
\hline 18CS-27-19 & 82.005 & 878.631 & 237.1 & 0.00422 & 0.1403 & 0.0018 & 2.6566 & 0.068 & 0.13684 & 0.0026 & 2231.5 & 22.07 & 1316.5 & 18.848 & 826.8 & 14.47 & $54 \%$ \\
\hline $18 \mathrm{CS}-27-20$ & 506.93 & 324.127 & 814.7 & 0.00123 & 0.1664 & 0.002 & 8.0428 & 0.221 & 0.3497 & 0.0078 & 2521.3 & 20.83 & 2235.8 & 24.777 & 1933 & 37.16 & $85 \%$ \\
\hline $18 \mathrm{CS}-27-21$ & 380.77 & 680.57 & 49.65 & 0.02014 & 0.0495 & 0.0014 & 0.1316 & 0.004 & 0.01929 & 0.0002 & 172.31 & 66.66 & 125.52 & 3.4689 & 123.2 & 1.0877 & $98 \%$ \\
\hline $18 \mathrm{CS}-27-22$ & 633.59 & 522.519 & 72.68 & 0.01376 & 0.053 & 0.0024 & 0.1455 & 0.007 & 0.01989 & 0.0003 & 327.84 & 97.21 & 137.93 & 6.069 & 127 & 1.9475 & $91 \%$ \\
\hline $18 \mathrm{CS}-27-23$ & 960.9 & 598.913 & 99.37 & 0.01006 & 0.0504 & 0.0014 & 0.1299 & 0.003 & 0.01871 & 0.0002 & 213.04 & 66.66 & 124.04 & 3.129 & 119.5 & 1.102 & $96 \%$ \\
\hline $18 \mathrm{CS}-27-24$ & 366.76 & 391.313 & 45.96 & 0.02176 & 0.066 & 0.0028 & 0.1724 & 0.007 & 0.01902 & 0.0002 & 809.26 & 88.89 & 161.52 & 5.6966 & 121.4 & 1.503 & $71 \%$ \\
\hline 18CS-27-25 & 1361.7 & 1031.35 & 149.1 & 0.00671 & 0.0483 & 0.0009 & 0.1301 & 0.003 & 0.01951 & 0.0002 & 122.31 & 44.44 & 124.18 & 2.4746 & 124.5 & 1.3435 & $99 \%$ \\
\hline
\end{tabular}

Table 3. Lu-Hf isotopic analysis result of the Chishan alkaline complex.

\begin{tabular}{|c|c|c|c|c|c|c|c|c|c|}
\hline Samples & ${ }^{176} \mathrm{Yb} /{ }^{177} \mathrm{Hf}$ & ${ }^{176} \mathrm{Lu} /{ }^{177} \mathrm{Hf}$ & ${ }^{176} \mathrm{Hf} /{ }^{177} \mathrm{Hf}$ & $2 \sigma$ & $\varepsilon \mathbf{H f}(0)$ & $\varepsilon \mathbf{H f}(\mathbf{t})$ & $\mathrm{T}_{\mathrm{DM}}(\mathrm{Ma})$ & $\mathrm{T}_{\mathrm{DM}} \mathrm{C}^{\mathrm{CMa}}$ & $f_{\mathrm{Lu} / \mathrm{Hf}}$ \\
\hline $18 \mathrm{CS} 01-03$ & 0.015576 & 0.000718 & 0.282282 & 0.000029 & -17.3 & -14.6 & 1359 & 2112 & -0.98 \\
\hline $18 \mathrm{CS} 01-08$ & 0.013584 & 0.000573 & 0.282248 & 0.000025 & -18.5 & -15.8 & 1400 & 2186 & -0.98 \\
\hline 18CS01-13 & 0.011379 & 0.000519 & 0.282322 & 0.000019 & -15.9 & -13.2 & 1296 & 2020 & -0.98 \\
\hline 18CS01-16 & 0.022202 & 0.000943 & 0.282299 & 0.000021 & -16.7 & -14.0 & 1343 & 2074 & -0.97 \\
\hline 18CS-27-02 & 0.020686 & 0.001017 & 0.282241 & 0.000018 & -18.8 & -16.1 & 1426 & 2203 & -0.97 \\
\hline 18CS-27-05 & 0.022520 & 0.001098 & 0.282317 & 0.000023 & -16.1 & -13.4 & 1324 & 2036 & -0.97 \\
\hline $18 C S-27-25$ & 0.022610 & 0.000942 & 0.282062 & 0.000024 & -25.1 & -22.4 & 1672 & 2601 & -0.97 \\
\hline
\end{tabular}

The following parameters were applied to the calculation: $\left({ }^{176} \mathrm{Lu} /{ }^{177} \mathrm{Hf}\right)_{\mathrm{CHUR}}=0.0332,\left({ }^{176} \mathrm{Hf} /{ }^{177} \mathrm{Hf}\right)_{\mathrm{CHUR}, 0}=0.282772[53] ;\left({ }^{176} \mathrm{Lu} /{ }^{177} \mathrm{Hf}\right)_{\mathrm{DM}}=0.0384,\left({ }^{176} \mathrm{Hf} /{ }^{177} \mathrm{Hf}\right)_{\mathrm{DM}, 0}=0.28325[54]$;

${ }^{176} \mathrm{Lu}$ decay constant $\lambda=1.867 \times 10^{-11} \mathrm{a}^{-1}[52]$. 


\section{Discussion}

\subsection{Rock Ages}

Zircon $\mathrm{U}-\mathrm{Pb}$ dating analysis demonstrated that in the Chishan alkaline complex, the quartz syenite formed at $125.8 \pm 1.2 \mathrm{Ma}$, and the alkali granite formed at $127.3 \pm 1.0 \mathrm{Ma}$, which concurs with the ages of the quartz syenite $(122.4 \pm 2.0 \mathrm{Ma})$ and aegirine quartz syenite porphyrite $(130.1 \pm 1.4 \mathrm{Ma})$ yielded by Liang et al. [35] through LA-MC-ICPMS zircon U-Pb measurement. This finding suggests that the rock complex formed in Early Cretaceous, which concurs with the ages of the late Mesozoic magmatic rocks extensively distributed in Eastern China [61]. According to Lan et al. [32], the dolomite $\mathrm{Rb}-\mathrm{Sr}$ age of the Chishan REE deposit ores is $119 \pm 1.4 \mathrm{Ma}$, which is a bit later than the emplacement of this alkaline rock complex, suggesting a close genetic connection between this alkaline rock system and mineralization of the REE ores in this area.

\subsection{Magmatic Sources and Evolution}

The Mesozoic Era witnessed three major geodynamic events in the North China lithosphere: collisional orogeny, tectonic regime transition, and mass lithospheric thinning [11]. Numerous alkaline intrusions emerged in the North China Craton [23], giving rise to various types of metal deposits. As the Chishan REE deposit represents a typical example of alkaline rock mineralization throughout the North China Craton [25], studying the material sources of alkaline rocks bears significance in the studies of both geodynamic mechanisms and metallogenic relationships.

The quartz syenite and alkali granite in the Chishan alkaline complex are rich in alkali (with a $\mathrm{Na}_{2} \mathrm{O}$ $+\mathrm{K}_{2} \mathrm{O}$ content of 7.62-10.94\%), high in potassium (with a $\mathrm{Na}_{2} \mathrm{O} / \mathrm{K}_{2} \mathrm{O}$ content of $0.28-0.89$ ), metaluminous (with an aluminum saturation index (A/CNK) of 0.75-1.00), and poor in $\mathrm{Ti}, \mathrm{Fe}, \mathrm{Mg}$, and $\mathrm{Mn}$, which are typical features of an alkaline rock series. The rocks feature strong LREE/HREE fractionation; the REEs display a right-inclined distribution pattern with weak positive and negative Eu anomalies (the $\delta \mathrm{Eu}$ is 1.16-4.15). For the similar compositions and close spatial relationship, we regard that quartz syenite and alkali granite are the members of one intrusion (Chishan alkaline complex).

On the $\mathrm{Ta} / \mathrm{Yb}-\mathrm{Th} / \mathrm{Yb}$ diagram (Figure 8) [62], the absolute majority of the rock samples from the Chishan alkaline complex fall within or near the enriched mantle zone, suggesting a close connection between the material sources of the Chishan alkaline rocks and enriched mantle. As reported by Yan et al. [27], the aegirine syenite features a Rb content of $170.46 \times 10^{-6}-4550.67 \times 10^{-6}, \mathrm{a}^{87} \mathrm{Rb} /{ }^{86} \mathrm{Sr}$ ratio of $2.6800-0.0500$, and a ${ }^{87} \mathrm{Sr} /{ }^{86} \mathrm{Sr}$ ratio of $0.71176-0.70780$. These findings agree with the geochemistry of mantle-derived magmas and are close to the features of an EMI (enriched mantle I)-type deposit. The rocks must have originated from highly enriched mantle-derived materials.

Zircons are well representative of the isotopic composition of magma sources as their high stability has guarded their $\mathrm{Lu}-\mathrm{Hf}$ isotopes from magmatic differentiation and late weathering processes. For this reason, zircon Lu-Hf isotopes are often used for tracing magma sources and magmatic evolution [55]. Zircon $\varepsilon H f(t)$ reflects the composition of a magma source. A positive $\varepsilon H f(t)$ represents a depleted mantle or a young, new crust overgrowing a depleted mantle and indicates remelting from the new crust. The negative $\varepsilon H f(t)$ values of the studied samples might indicate Chishan alkaline complex was originated from an enriched mantle source or thickened lower crust or a mixed source region $[55,63,64]$. Given that the quartz syenite and alkali granite of the Chishan Alkaline Complex share the same zircon Hf isotopic composition with relatively low $\varepsilon \mathrm{Hf}(\mathrm{t})$ values $(-17.60-13.19)$, the Hf isotopic compositions fall above the $2.5 \mathrm{Ga}$ continental crust evolutional line on the diagram for $T-\varepsilon \operatorname{Hf}(\mathrm{T})$ (Figure 9), and represent a mixing of mantle sources with remobilized old continental crust. Also, the results are consistent with those of the contemporary Longbaoshan alkaline complex $(\varepsilon H f(t)=-19.20$ to -14.00$)$ [65], which is believed to be produced by partial melting of the enriched lithospheric mantle (EMI) [66-69]. Further, there showed some inherited zircons in the alkali granite. Specially, the ages and Hf isotopes composition of inherited zircon cores could be an important and critical clue to identify the mantle source of rocks. Although, the ages and Hf isotopes of the inherited 
zircons cores in Chishan complex were not measured this time, the late Archean ages (2.51-2.64 Ga) with positive $\varepsilon \mathrm{Hf}(\mathrm{t})$ values $(-0.2$ to -6.2$)$ derived from inherited zircon cores of the Longbaoshan complex [65] suggest that the ancient crust of the North China Craton was also involved in the formation of those alkaline complex. Thus, it is reasonable to deduce that the Chishan alkaline complex originated from partial of the EMI-type lithospheric mantle with assimilation of ancient crustal materials.

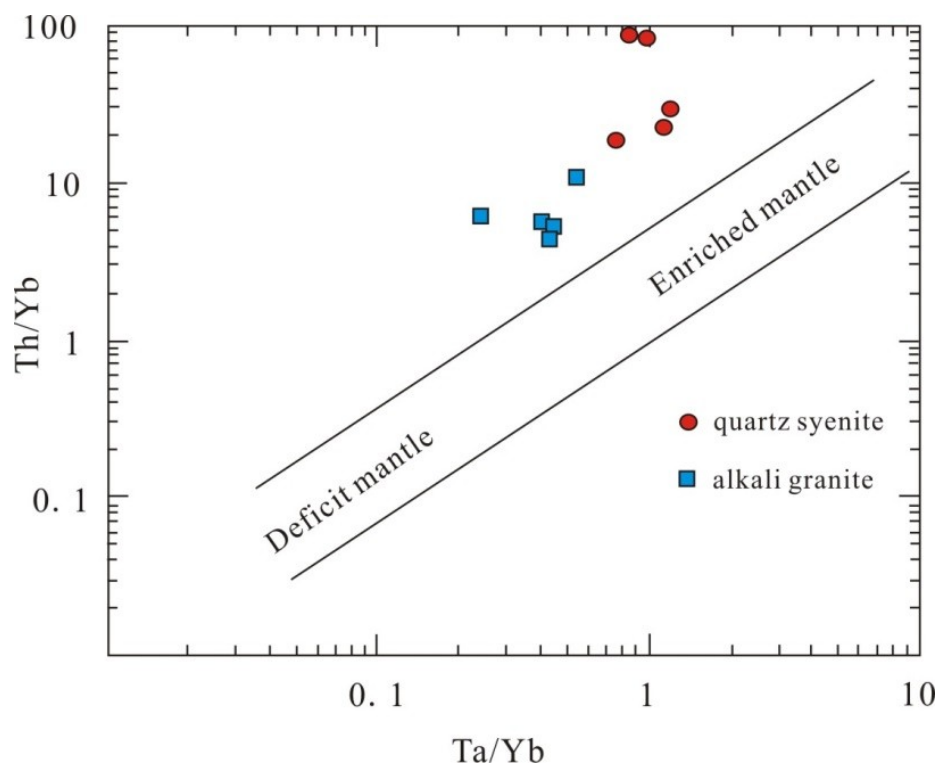

Figure 8. $\mathrm{Ta} / \mathrm{Yb}-\mathrm{Th} / \mathrm{Yb}$ diagram of the Chishan alkaline complex. The diagram is from [62].

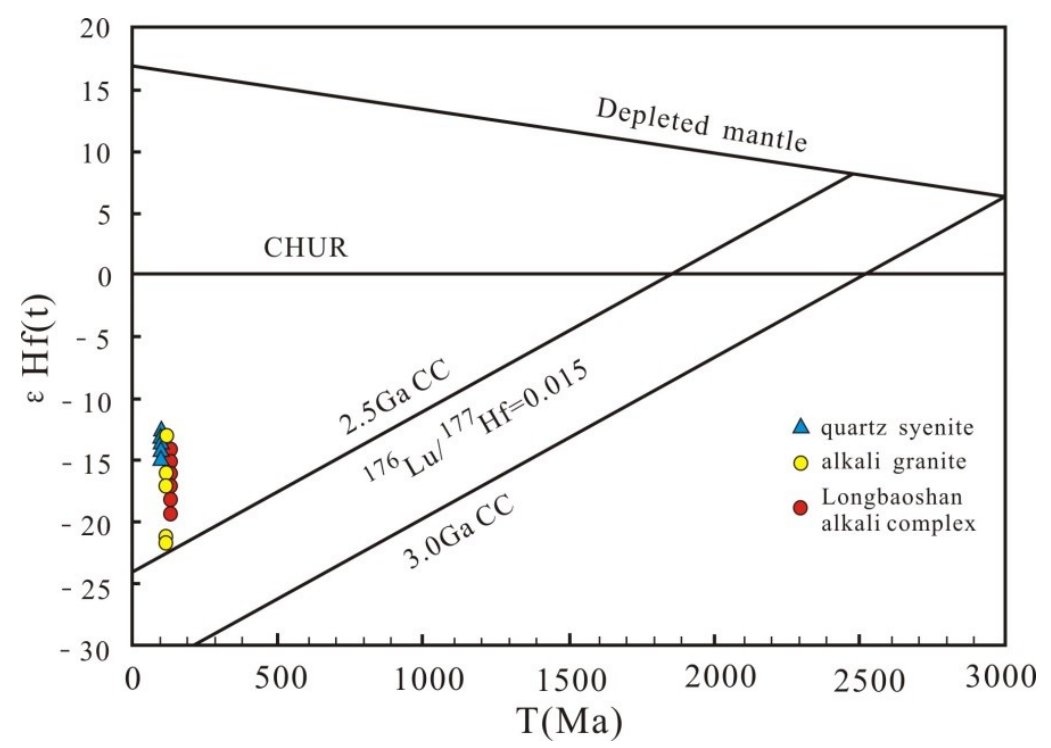

Figure 9. Zircon Hf isotope diagram of Chishan alkali complex. Other data sources: Longbaoshan alkaline complex [65].

Furthermore, in terms of $\mathrm{Nd}$ isotopic composition, the $\varepsilon \mathrm{Nd}(\mathrm{t})$ value of the Chishan alkaline rocks is -8.7 to -8.11 [70], the $\varepsilon \mathrm{Nd}(\mathrm{t})$ value of the Neoarchean gneiss basement is -25 [70], and the $\varepsilon \mathrm{Nd}(\mathrm{t})$ of the Early Cretaceous (125-127 Ma) basic magmatic rocks (e.g., the Fangcheng basalt and Yinan gabbro) in Western Shandong, which directly originate from the partial melting of an enriched mantle, ranges from -15.4 to $-12.6[67,69]$. Such a condition indicates that the Chishan alkaline rocks could never have derived from the crust. Rather, these rocks must have been associated with an enriched mantle. The $\varepsilon N d(t)$ value of the perovskite and monazite in the Chishan REE ore veins is -10.1 
to -8.2 [32], which agrees with the Nd isotopic composition of the alkaline rocks, confirming that the alkaline rocks are of the same origin as the REE ores.

\subsection{Tectonic Setting}

Intense tectonic activities, including three major geodynamic events (collisional orogeny, mass lithospheric thinning, and tectonic regime transition within the North China Craton since the Mesozoic), have resulted in extensive magmatic and metallogenic processes $[11,67]$. During the Triassic, the collision between the North China and Yangtze Plates gave rise to the Dabie-Sulu ultrahigh-pressure metamorphic zone. In the Early Jurassic (180-130 Ma), the lithosphere started thinning. The Yangtze Plate underplated the North China Plate after a deep subduction. Mantle-derived magmas reached the Tanlu fault zone to the crust-mantle boundary. Crustal thickening and remelting triggered a string of magmatic processes, giving rise to high $\mathrm{K}$ calc-alkaline to high $\mathrm{K}$ alkaline rocks. The lithospheric mantle changed to an EMII-type deposit [67]. In the Early Cretaceous (130-90 Ma), when Western Shandong was in a backarc extensional environment caused by the subduction of the Yangtze Plate toward the North China Plate, the lithosphere thinned enormously, and extensive enriched mantle melting occurred. The tectonic stress regime also changed from extrusion toward extension. Mass uptrusion of asthenospheric mantle materials, along with mass diagenetic processes, caused the formation of late Mesozoic alkaline rocks [11,65,71-74].

From the $\lg \left(\mathrm{CaO} / \mathrm{Na}_{2} \mathrm{O}+\mathrm{K}_{2} \mathrm{O}\right)-\mathrm{SiO}_{2}$ discrimination diagram (Figure 10a) [75], the rock projection points of the Chishan alkaline complex mostly fall within the extensional alkaline-alkalilime rock zone, demonstrating that the rocks formed in an extensional tectonic setting. On the $\omega(\mathrm{Rb})-\omega(\mathrm{Y}+\mathrm{Nb})$ discrimination diagram (Figure 10b) [76], all the samples fall within the post-collisional granite zone, and the diagenetic background is an active continental margin. These findings also confirm that the Chishan alkaline complex formed in an extensional tectonic setting. The source region of the rocks is closely associated with the tectonic setting of their origin. The source region of post-collisional granite normally results from the mantle contaminated by a part of the crustal materials. The negative $\mathrm{Nb}, \mathrm{Ta}$, and Ti anomalies in the rocks are comparative to those of an island arc tectonic setting [77], concurring with the mass lithospheric detachment and thinning background in Eastern China during the Mesozoic [78-81]. This condition suggests that the formation of the Chishan alkaline complex was controlled by the lithospheric thinning of the North China Craton; it must have originated from a backarc extensional setting caused by plate subduction.

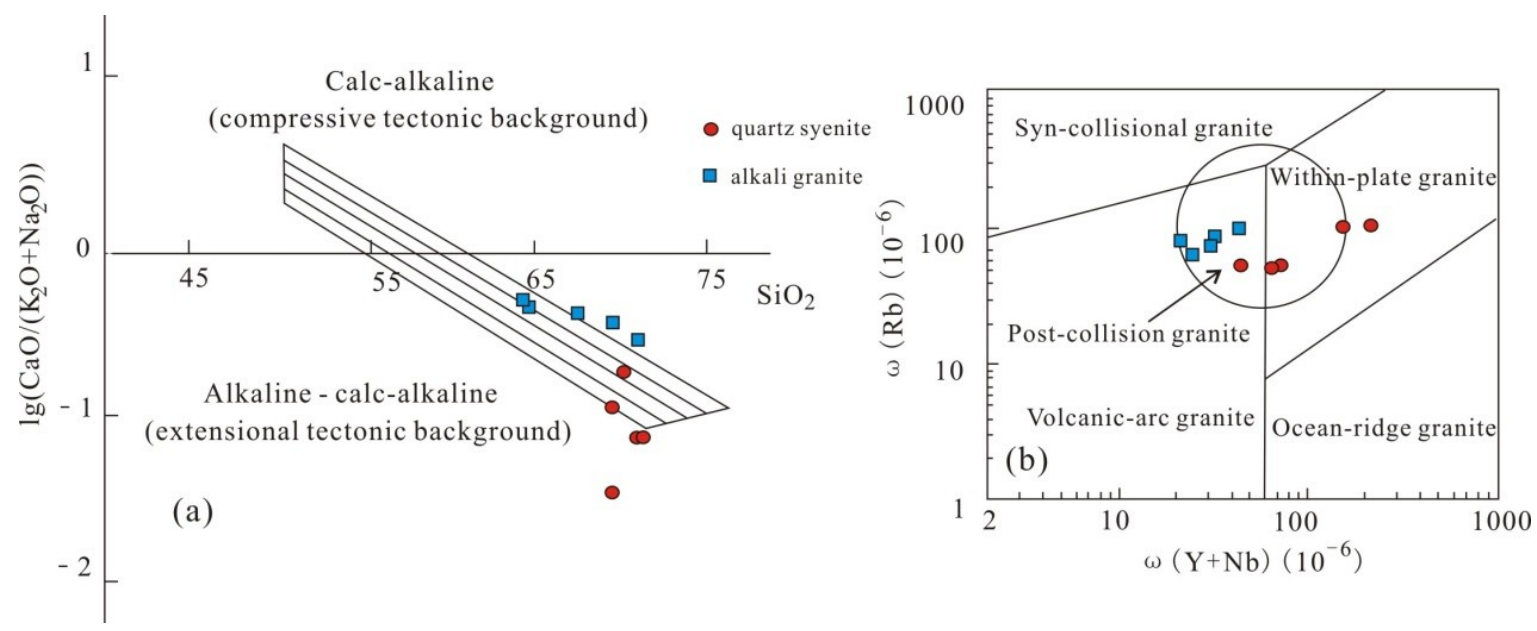

Figure 10. $\lg \left(\mathrm{CaO} /\left(\mathrm{Na}_{2} \mathrm{O}+\mathrm{K}_{2} \mathrm{O}\right)\right)-\mathrm{SiO}_{2}(\mathbf{a})$ and $\mathrm{Rb}-(\mathrm{Y}+\mathrm{Nb})(\mathbf{b})$ discrimination diagrams of the Chishan alkaline complex. (a) is from [75], (b) is from [76]. 


\section{Conclusions}

(1) The Chishan alkaline complex formed in the Early Cretaceous. The quartz syenite and alkali granite formed at $125.8 \pm 1.2$ and $127.3 \pm 1.0 \mathrm{Ma}$, respectively, and are closely associated with the mineralization of the Weishan REE deposit.

(2) The Chishan alkaline complex shows the geochemistry of mantle-derived magmas features and originated from partial of the EMI-type lithospheric mantle with assimilation of ancient crustal materials. The complex must be of the same origin as the REE deposit.

(3) The formation of the Chishan alkaline complex developed in an extensional setting that resulted from subduction of the North China and Yangtze Plates, and lithospheric thinning and upwelling in the eastern the North China Craton.

Author Contributions: Conceptualization: P.W.; formal analysis: Y.Z. and Y.S.; investigation: Q.L., L.Y., and N.C.; data curation: Z.L. and K.G.; writing-original draft preparation: P.W.; writing-review and editing: X.Y., D.L., and L.Y.

Funding: This study was financially supported by the National Natural Science Foundation of China, grant nos. 41503038, 41140025, 41672084, and 41372086; Postdoctoral Innovation Project of Shandong Province, grant no. 201703091; Special fund for "Taishan scholars" project in Shandong Province; the Key R and D Program of Shandong Province, Grant No. 2017CXGC1601, 2017CXGC1602, 2017CXGC1603; Key R and D Program of China, grant nos. 2016YFC0600105-04, 2016YFC0600606; and the Shandong Provincial Key Laboratory of Depositional Mineralization and Sedimentary Mineral, grant no. DMSM2018028.

Acknowledgments: The authors are grateful to manager XinZhu Zhang and Dejian Li of the Shandong Weishan Lake REE Co. Ltd. for permission to access the mining project. Tingbao Han and Guangsuo Cheng are thanked for their help during the connection with REE Co. Ltd. Xiaowei Li (China University of Geosciences Beijing) are thanked for his help during the revising process.

Conflicts of Interest: The authors declare no conflict of interest.

\section{References}

1. Deng, J.F.; Mo, X.X.; Zhao, H.L.; Luo, Z.H.; Du, Y.S. Lithospheric root/de-rooting and activation. J. Grad. Sch. China Univ. Geosci. 1994, 8, 350-356, (In Chinese with English abstract).

2. Deng, J.F.; Zhao, H.L.; Mo, X.X.; Wu, Z.X.; Luo, Z.H. Continental Roots-Plume Tectonics of China-Key to the Continental Dynamics; Geological Publishing House: Beijing, China, 1996; pp. 1-110. (In Chinese)

3. Wu, F.Y.; Sun, D.Y.; Lin, Q. Petrogenesis of the Phanerozoic granites and crustal growth in the Northeast China. Acta Pet. Sin. 1999, 15, 181-189, (In Chinese with English abstract).

4. Wu, F.Y.; Sun, D.Y. The Mesozoic magmatism and lithospheric thinning in the eastern China. J. Chang. Univ. Sci. Tech. 1999, 29, 313-318, (In Chinese with English abstract).

5. Shao, J.A.; Liu, F.T.; Chen, H.; Han, Q.J. Relationship between Mesozoic magmatism and subduction in Da Hinggan-Yanshan Area. Acta Geol. Sin. 2001, 75, 56-63, (In Chinese with English abstract).

6. Zhang, Q.; Wang, Y.; Yang, J.H.; Wang, Y.L.; Zhao, T.P.; Guo, G.J. The Characteristics and tectonic-metallogenetic significances of the adakites in the Yanshanian Period from eastern China. Acta Pet. Sin. 2001, 17, 236-244, (In Chinese with English abstract).

7. Zhang, Q.; Wang, Y.; Wang, Y.L. Preliminary study on the components of the lower crust in east China plateau during Yanshanian period: Constraints on $\mathrm{Sr}$ and $\mathrm{Nd}$ isotopic compositions of adakite-like rocks. Acta Pet. Sin. 2001, 17, 505-513, (In Chinese with English abstract).

8. Zhai, M.G.; Fan, Q.C. Mesozoic replacement of bottom crust in North China Craton: An orogenic mantle-crust interaction. Acta Pet. Sin. 2002, 18, 1-8, (In Chinese with English abstract).

9. Hu, S.X.; Zao, Y.Y.; Hu, Z.H.; Guo, J.C.; Xu, B. Evolution and decelopment of tectonics and magmatism at the active continental margin of the East China(E106 $\left.{ }^{\circ}\right)$ during Mesozoic and Cenozoic. Acta Pet. Sin. 1994, 10, 370-381.

10. Chen, Y.J.; Guo, Y.J.; Guo, G.J.; Li, X. Metallogenic geodynamic background of Mesozoic gold deposits in the huabei craton granite greenstone terrane. Sci. China Earth Sci. 1998, 28, 35-40.

11. Mao, J.W.; Zhang, Z.H.; Yu, J.J.; Wang, Y.T.; Niu, B.G. Geodynamics of Mesozoic large-scale mineralization in north China and its adjacent areas: implications from precise dating of metallic deposit. Sci. China Earth Sci. 2003, 4, 289-299. 
12. Li, J.W.; Bi, S.J.; Selby, D.; Chen, L.; Vasconcelos, P.; Thiede, D.; Zhou, M.F.; Zhao, X.F.; Li, Z.K.; Qiu, H.Z. Giant Mesozoic gold procinces related to the destruction of the North China carton. Earth Planet Sci. Lett. 2012, 349-350, 26-37. [CrossRef]

13. Zhai, M.; Santosh, M. Metallogeny of the North China carton: Link with secular changes in the evolving Earth. Gondwana Res. 2013, 24, 275-297. [CrossRef]

14. Chen, Y.J.; Franco, P.; Lai, Y.; Li, C. Metallogenic time and tectonic setting of the Jiaodong gold province, eastern China. Acta Pet. Sin. 2004, 20,907-922.

15. Mao, J.W.; Pirajno, F.; Xiang, J.F.; Gao, J.J.; Ye, H.S.; Li, Y.F.; Guo, B.J. Mesozoic molybdenum deposits in the east Qinling-Dabie oro-genic belt: Characteristics and tectonic settings. Ore Geol. Rev. 2011, 43, $264-293$. [CrossRef]

16. Goldfarb, R.J.; Santosh, M. The dilemma of the Jiaodong gold deposits: Are they unique? Geosci. Front. 2014, 5, 139-153. [CrossRef]

17. Yang, J.H.; Zhou, X.H. Rb-Sr, $\mathrm{Sm}-\mathrm{Nd}$ and $\mathrm{Pb}$ isotope systematics of pyrite: implications for the age and genesis of lode gold deposits. Geology 2001, 29, 711-714. [CrossRef]

18. Chen, Y.J.; Pirajno, F.; Qi, J.P. Origin of gold metallogeny and sources of ore-forming fluids, in the Jiaodong province, eatern China. Int. Geol. Rev. 2005, 47, 530-549. [CrossRef]

19. Li, J.J.; Luo, Z.K.; Liu, X.Y.; Xu, W.D.; Chen, A.S. The zircon Shrimp U-Pb age of the granite-porphyry veins after mineralization in linglong gold deposit restricts the evolution of the Jiaobei terrains. Earth Sci. Front. 2005, 12, 317-324.

20. Wu, F.Y.; Lin, J.Q.; Wilde, S.A.; Zhang, X.; Yang, J.H. Nature and significance of the Early Cretaceous giant igneous event in eastern China. Earth Planet. Sci. Lett. 2005, 233, 103-119. [CrossRef]

21. Hou, M.L.; Jiang, S.Y.; Jiang, Y.H.; Li, H.F. S-Pb isotope geochemistry and Rb-Sr geochronology of the Penglai gold field in the eastem Shangdong province. Acta Pet. Sin. 2006, 22, 2525-2533, (In Chinese with English abstrcat).

22. Jiang, S.Y.; Dai, B.Z.; Jiang, Y.H.; Zhao, H.X.; Hou, M.L. Jiaodong and Xiaoqinling: Two orogenic gold provinces formed in different tectonic settings. Acta Pet. Sin. 2009, 25, 2727-2738, (In Chinese with English abstract).

23. Lan, T.G.; Fan, H.R.; Santosh, M.; Hu, F.F.; Yang, K.F.; Yang, Y.H. Early Jurassic high-K calc-alkaline and shoshonitic rocks from the Tongshi intrusive complex, eastern North China Craton: Implication for crust-mantle interaction and post-collisional magmatism. Lithos 2012, 140-141, 183-199. [CrossRef]

24. Tian, J.X.; Li, X.X.; Song, Z.Z.; Liu, H.D.; Huang, Y.B.; Zhu, D.C. Environment, formation age and material sources of Mesozoic Gold deposits in Western Shandong: A Synthesis. Acta Geol. Sin. 2015, 89, 1530-1537.

25. Tian, J.X.; Zhang, R.T.; Fan, Y.C.; Li, X.Z.; Xu, H.Y.; Wang, B.Y. Geological characteristics and relation with rare earth elements of alkalic complex in Chishan of Shandong Province. Shandong Geol. 2002, 18, 21-25.

26. Kong, Q.Y.; Li, J.K.; Yu, X.F. Shandong Deposit; Shandong Science \& Technology Press: Jinan, China, 2006; pp. 1-902.

27. Yan, G.H.; Cai, J.H.; Ren, K.X.; Mu, B.L.; Chu, Z.Y. Nd, Sr and Pb isotopic geochemistry of late-Mesozoic alkaline-rich intrusions from the Tanlu Fault zone: evidence of the magma soucre. Acta Pet. Sin. 2008, 24, 1223-1236.

28. Yu, X.F.; Tang, H.S.; Han, Z.Z.; Li, C.Y. Geological characteristics and origin of rare earth elements deposits related with alkaline rock in the Chishan-Longbaoshan area, Shandong Province. Acta Geol. Sin. 2010, 84, 407-417.

29. Yuan, Z.X.; Li, J.K.; Wang, D.H.; Zheng, G.D.; Lou, D.B.; Chen, Z.H.; Zhao, Z.; Yu, Y. Metallogenetic Regularity of Rare Earth Deposits in China; Geological Publishing House: Beijing, China, 2012; pp. 1-116.

30. Wang, J.F.; Sun, M.T.; Du, X.B.; Gan, Y.J.; Zhang, G.Q.; Wang, Z.L. Geological characteristics and prospecting potentiality of Xishan rare earth deposit in Shandong Province. Shandong Land Res. 2016, 32, 32-40.

31. Li, J.K.; Yuan, Z.X.; Bai, G.; Chen, Y.C.; Wang, D.H.; Ying, L.J.; Zhang, J. Ore-forming fluid evolvement and its controlling to REE (AG) mineralizing in the Weishan deposit, Shandong. J. Min. Pet. 2009, 29, 60-68.

32. Lan, T.G.; Fan, H.R.; Hu, F.F.; Yang, K.F.; Wang, Y. Genesis of the Weishan REE deposit, Shandong Province: Evidences from $\mathrm{Rb}-\mathrm{Sr}$ isochron age, LA-MC-ICPMS Nd isotopic compositions and fluid inclusions. Geochimica 2011, 40, 428-442.

33. Zhou, W.W.; Cai, J.H.; Yan, G.H. The geochemical characteristics and geological significance of alkaline complex in Chishan of Shandong Province. Northwestern Geol. 2013, 46, 93-105. 
34. Yu, X.F.; Tang, H.S.; Li, D.P. Study on the Mineralization of Chishan Rare Earth Element Deposit Related to Alkaline Rock, Shandong Province. Acta Geol. Sin. (Engl. Ed.) 2014, 88, 480-481. [CrossRef]

35. Liang, Y.W.; Lai, Y.; Hu, H.; Zhang, F. Zircon U-Pb Ages and Geochemical Characteristics Study of Syenite from Weishan REE Deposit, Western Shandong. Acta Sci. Nat. Univ. Pekin 2017, 53, 652-666.

36. Zhu, G.; Liu, G.S.; Niu, M.L.; Song, C.Z.; Wang, D.X. Transcurrent movement and genesis of the Tan-Lu Fault Zone. Geol. Bull. China 2003, 22, 200-207, (In Chinese with English abstract).

37. Zhang, X.M.; Zhang, Y.Q.; Ji, W. Fault distribution patterns of the Luxi Block, Shandong, and Mesozoic sedimentary-magmatic-structural evolution sequence. J. Geomech. 2007, 13, 163-172, (In Chinese with English abstract).

38. Chen, L.; Tao, W.; Zhao, L.; Zhen, T.Y. Distinct lateral variation of lithospheric thickness in the Northeastern North China Craton. Earth Planet. Sci. Lett. 2008, 267, 56-68. [CrossRef]

39. Zhao, G.; Wilde, S.A.; Guo, J.H.; Cawood, P.A.; Sun, M.; Li, X.P. Single zircon grains record two Paleoproterozoic collisional events in the North China Craton. Precambrian Res. 2010, 177, 266-276. [CrossRef]

40. Zhao, G.C.; Wilde, S.A.; Cawood, P.A.; Sun, M. Archean blocks and their boundaries in the North China Craton: Lithological, geochemical, structural and P-T pathconstraints and tectonic evolution. Precambrian Res. 2001, 107, 45-73. [CrossRef]

41. Li, J.; Jin, A.; Hou, G. Timing and implications for the late Mesozoic geodynamic settings of eastern North China Craton: Evidences from K-Ar dating age and sedimentary-structural characteristics records of Lingshan Island, Shandong Province. J. Earth Syst. Sci. 2017, 126, 117. [CrossRef]

42. Wang, S.J.; Li, X.P.; Schertl, H.P.; Feng, Q.D. Petrogenesis of early cretaceous andesite dykes in the Sulu orogenic belt, eastern China. Mineral. Petrol. 2019, 113, 77-97. [CrossRef]

43. Li, R.; Albert, N.N.; Yun, M.; Meng, Y.; Du, H. Geological and Geochemical Characteristics of the Archean Basement-Hosted Gold Deposit in Pinglidian, Jiaodong Peninsula, Eastern China: Constraints on Auriferous Quartz-Vein Exploration. Minerals 2019, 9, 62. [CrossRef]

44. Han, C.; Han, M.; Jiang, Z.X.; Han, Z.Z.; Li, H.; Song, Z.G.; Zhong, W.J.; Liu, K.X.; Wang, C.H. Source analysis of quartz from the Upper Ordovician and Lower Silurian black shale and its effects on shale gas reservoir in the Southern Sichuan Basin and its periphery, China. Geol. J 2019, 54, 439-449. [CrossRef]

45. Wang, J.; Wang, X.; Liu, J.; Liu, Z.; Zhai, D.; Wang, Y. Geology, geochemistry, and geochronology of gabbro from the Haoyaoerhudong gold deposit, Northern Margin of the North China Craton. Minerals 2019, 9, 63. [CrossRef]

46. Kong, Q.Y.; Zhang, T.Z.; Yu, X.F.; Xu, J.X.; Pan, Y.L.; Li, X.S. Deposits in Shandong Province; Shandong Science and Technology Press: Jinan, China, 2006; pp. 1-902. (In Chinese)

47. Song, B.; Zhang, Y.H.; Wan, Y.S.; Jian, P. Mount Making and procedure of the SHRIMP Dating. Geol. Rev. 2002, 48, 26-30, (In Chinese with English abstract).

48. Yuan, H.; Gao, S.; Liu, X.; Li, H.; Günther, D.; Wu, F. Accurate U-Pb age and trace element determinations of zircon by laser ablation-inductively coupled plasma-mass spectrometry. Geostand. Geoanal. Res. 2010, 28, 353-370. [CrossRef]

49. Liu, Y.S.; Hu, Z.C.; Gao, S.; Xu, J.; Gao, C.G.; Chen, H.H. In suit analysis of major and trace elements of anhydrous minerals by LA-ICP-MS without applying an internal standard. Chem. Geol. 2008, 257, 34-43. [CrossRef]

50. Ludwig, K.R. User's Manual for Isoplot 3.70, A Geolocro-Nological Toolkit for Microsoft Excel; Berkeley Geochronology Center Special Publication: Berkeley, CA, USA, 2003; Volume 4, pp. 25-32.

51. Geng, J.Z.; Li, H.K.; Zhang, J.; Zhou, H.Y.; Li, H.M. Zircon Hf isotope analysis by means of LA-MC-ICP-MS. Geol. Bull. China 2011, 30, 1508-1513, (In Chinese with English abstract).

52. Soderlund, U.; Patchett, P.J.; Vervoort, J.D.; Isachsen, C.E. The ${ }^{176} \mathrm{Lu}$ decay constant determined by Lu-Hf and U-Pb isotope systematics of Precambrian mafic instrusions. Earth Planet Sci. Lett. 2004, 219, 311-324. [CrossRef]

53. Bichert-Toft, J.; Albarede, F. The Lu-Hf geochemistry of chondrites and the evolution of the mantle-crust system. Earth Planet. Sci. Lett. 1997, 148, 243-258. [CrossRef]

54. Griffin, W.L.; Pearson, N.J.; Belousova, E.; Jackson, S.E.; Achterbergh, E.V.; O’Reilly, S.Y.; Shee, S.R. The Hf isotope composition of cratonic mantle: LAM-MC-ICPMS analysis of zircon megacrysts in kimberlites. Geochim. Cosmochim. Acta. 2000, 64, 133-147. [CrossRef] 
55. Wu, F.Y.; Li, X.H.; Zheng, Y.F.; Gao, S. Lu-Hf isotopic systematics and their applications in petrology. Acta Pet. Sin. 2007, 23, 185-220, (In Chinese with English abstract).

56. Middlemost, E.A.K. Naming materials in the magma/igneous rock system. Earth Sci. Rev. 1994, 37, $215-224$. [CrossRef]

57. Wright, J.B. A simple alkalinity ratio and its application to questions of nonorogenic granite genesis. Geol. Mag. 1969, 106, 370-384. [CrossRef]

58. Peccerillo, A.; Taylor, S.R. Geochemistry of Eocene calc-alkaline volcanic rocks from the Kastamonu, northern Turkey. Contrib. Mineral. Petrol. 1976, 58, 63-81. [CrossRef]

59. Sun, S.S.; McDonough, W.F. Chemical and isotopic systematics of oceanic basalts: implications for mantle composition and processes. In Magmatism in the Oceanic Basalts; Saunders, A.D., Norry, M.J., Eds.; Geological Society Special Publication: London, UK, 1989; pp. 313-345.

60. Vervootr, J.D.; Patchett, P.J.; Gehrels, G.E.; Nutman, A.P. Constraints on Earth differentiation from hafnium and neodymium. Nature 1996, 379, 624-627.

61. Guo, P. A Study on the Geodynamic Background of Mesozoic Gold Mineralization in Western Shandong. Ph.D. Thesis, China University of Geosciences (Beijing), Beijing, China, 2014.

62. Wilson, M. Igneous Petrogenesis: Agobal Tectonic Approach; Unwin Hyman: London, UK, 1989; pp. 1-466.

63. Kinny, P.D. Lu-Hf and Sm-Nd isotope systems in zircon. Rev. Mineral. Geochem. 2003, 53, 327-341. [CrossRef]

64. Sui, Z.M.; Ge, W.C.; Wu, F.Y.; Xu, X.C.; Zhang, J.H. Hf isotopic characteristics and geological significance of the Chahayan Pluton in northern Daxing'anling Mountains. J. Jilin Univ. Earth Sci. Ed. 2009, 39, 849-867, (In Chinese with English abstract).

65. Lan, T.G.; Fan, H.R.; Hu, F.F.; Tomkins, A.G.; Yang, K.F.; Liu, Y. Multiple crust-mantle interactions for the destruction of the north china craton: Geochemical and $\mathrm{Sr}-\mathrm{Nd}-\mathrm{Pb}-\mathrm{Hf}$ isotopic evidence from the longbaoshan alkaline complex. Lithos 2011, 122, 87-106. [CrossRef]

66. Xu, Y.G. Thermo-tectonic destruction of the Archean lithospheric keel beneath the Sino-Korean Craton: Evidence, timing and mechanism. Phys. Chem. Earth Part A Solid Earth Geod. 2001, 26, 747-757. [CrossRef]

67. Xu, Y.G.; Huang, X.L.; Ma, J.L.; Wang, Y.B.; Iizuka, Y.; Xu, J.F. Crust-mantle interaction during the tectono-thermal reactivation of the North China Craton: constraints from SHRIMP zircon U-Pb chronology and geochemistry of Mesozoic plutons from western Shandong. Contrib. Mineral. Petrol. 2004, 147, 750-767. [CrossRef]

68. Xu, Y.G.; Ma, J.L.; Huang, X.L.; lizuka, Y.; Chung, S.L.; Wang, Y.B.; Wu, X.Y. Early Cretaceous gabbroic complex from Yinan, Shandong Province: petrogenesis and mantle domains beneath the North China Craton. Int. J. Earth Sci. 2004, 93, 1025-1041. [CrossRef]

69. Zhang, H.F.; Sun, M.; Zhou, X.H.; Fan, W.M.; Zhai, M.G.; Yin, J.F. Mesozoic lithosphere destruction beneath the North China Craton: Evidence from major-trace-element and $\mathrm{Sr}-\mathrm{Nd}-\mathrm{Pb}$ isotope studies of Fangcheng basalts. Contrib. Mineral. Petrol. 2002, 144, 241-253. [CrossRef]

70. Xu, G.Z.; Zhou, R.; Wang, Y.F.; She, H.Q.; Li, B.; Du, B.M.; Song, M.C. The intrinsic factors causing the significant differences in Mesozoic mineralization between Jiaodong and Luxi areas. Geoscience 2002, 16, 9-18, (In Chinese with English abstract).

71. Li, Z.X. Collision between the North and South China Blocks: a Crustal-detachment model for the suturing in the region east of the Tanlu fault. Geology 1994, 22, 739-742. [CrossRef]

72. Hu, H.B.; Mao, J.W.; Niu, S.Y.; Li, Y.F.; Li, M.W. Geology and geochemistry of telluride-bearing Au deposits in the Pingyi area, Western Shandong, China. Mineral. Petrol. 2006, 87, 209-240. [CrossRef]

73. Chen, Y.J.; Zhai, M.G.; Jiang, S.Y. Significant achievements and open issues in study of orogenesis and metallogenesis surrounding the North China continent. Acta Pet. Sin. 2009, 25, 2695-2726.

74. Dong, G.; Santosh, M.; Li, S.; Shen, J.; Mo, X.; Scott, S. Mesozoic magmatism and metallogenesis associated with the destruction of the North China Craton: Evidence from $\mathrm{U}-\mathrm{Pb}$ geochronology and stable isotope geochemistry of the Mujicun porphyry Cu-Mo deposit. Ore Geol. Rev. 2013, 53, 434-445. [CrossRef]

75. Brown, G.C. Calcalkaline Intrusive Rocks: Their Diversity, Evolution and Relation to Volcanic Arcs; John Wiley \& Sons Inc.: Hoboken, NJ, USA, 1982; pp. 437-461.

76. Pearce, J.A. Source and settings of granite genesis. Geol. Mag. 1969, 106, 370-384.

77. Zhao, Z.H. Use the trace element diagram to discriminate tectonic settings. Geotectonica Et Metalogenia 2007, $31,92-103$. 
78. Wu, F.Y.; Sun, D.Y.; Zhang, G.L.; Ren, X.W. Deep geodynamics of Yanshain Movement. Geol. J. China Univ. 2000, 6, 379-388.

79. Hong, D.W.; Wang, T.; Tong, Y.; Wang, X.X. Break-up of the North China Craton through Lithospheric Thinning. Earth Sci. Front. 2003, 10, 232-249.

80. Zhou, X.H.; Zhang, H.F. High chemical heterogeneity of lithospheric mantle and continental lithospheric transition in north China during Mesozoic. Earth Sci. J. China Univ. Geosci. 2006, 31, 8-13.

81. Ji, S.C.; Wan, Q.; Xu, Z.Q. Break-up of the North China Craton through Lithospheric Thinning. Acta Geol. Sin. 2008, 82, 175-193. article distributed under the terms and conditions of the Creative Commons Attribution (CC BY) license (http://creativecommons.org/licenses/by/4.0/). 